\title{
FORUM
}

\section{Fruit Fly (Diptera: Tephritidae) Research in Latin America: Myths, Realities and Dreams}

\author{
Martín Aluja \\ Instituto de Ecología, A.C., Apartado Postal 63, C.P. 91000 , \\ Xalapa, Veracruz, Mexico
}

This article is dedicated to J.S. Morgante, R.A. Zucchi, A. Malavasi, F.S. Zucoloto, A.S. Nascimento, S. Bressan, L.A.B. Salles, and A. Kovaleski who have greatly contributed to our knowledge on fruit flies and their parasitoids in Latin America

An. Soc. Entomol. Brasil 28(4): 565-594 (1999)

A Pesquisa com Moscas-das-Frutas (Diptera: Tephritidae) na América Latina: Mitos, Realidade e Perspectivas

\begin{abstract}
RESUMO - Apresento uma avaliação crítica da pesquisa com moscas-das-frutas na América Latina baseada na noção de que muitos mitos e mal-entendidos são transmitidos a estudantes, jovens pesquisadores ou administrações oficiais. Pondero que depois de um esclarecedor início de século, durante o qual muitas descobertas significativas foram feitas sobre a história natural desses insetos, pouco progresso tem sido observado em muitas áreas de pesquisas e manejo de moscas-das-frutas na América Latina durante os últimos 50 anos. Isso tem sido causado em parte pela escassez de estudos sob condições naturais, bem com pela abordagem reducionista utilizada no estudo desses insetos maravilhosos, considerando as espécies individualmente, ou apenas as espécies-praga. Para interromper esse círculo vicioso, proponho que demos mais atenção à história natural das espécies, independente de sua importância econômica, ampliemos o escopo e o período de tempo de nossos estudos, fortaleçamos os fundamentos teóricos e ecológicos das pesquisas com moscas-das-frutas na América Latina e enfatizemos o enfoque comparativo sempre que possível. Apresento vários mitos sobre moscas-das-frutas (p.ex., o status de certos frutos como hospedeiros de moscas-das-frutas e de certas espécies como pragas), reviso o estado-de-arte de muitas áreas das pesquisas com moscas-das-frutas na América Latina e discuto algumas possibilidades para futuros estudos. Concluo propondo que no limiar do novo milênio, o tempo parece apropriado para seguir aqueles primeiros pioneiros e novamente impulsionar nosso entendimento da biologia, ecologia e comportamento da moscas-das-frutas. Para alcançar isso, necessitamos gerar novos paradigmas e promover o pensamento criativo entre nossos estudantes.
\end{abstract}

PALAVRAS-CHAVE: Insecta, Anastrepha, Toxotrypana.

ABSTRACT - I offer a critical assessment of fruit fly research in Latin America based on the notion that many myths and misconceptions are forced upon stu- 
dents and young scientists or government officials. I argue that after an enlightening beginning of the century, during which many significant discoveries were made about the natural history of these insects, little progress has been observed in many areas of fruit fly research and management in Latin America during the past 50 years. This has been caused in part by the reductionist, single-species or pest-only approaches followed in the study of these marvelous insects, as well as by the scarcity of studies under natural conditions. To break this vicious cycle, I propose that we pay more attention to the natural history of non-pest and pest species, broaden the scope and widen the time scale of our studies, strengthen the theoretical and ecological underpinnings of fruit fly research in Latin America and foster the comparative approach whenever possible. I present several fruit fly myths (e.g., the status of certain fruits as fruit fly hosts and certain species as pests), review the status of knowledge in most areas of fruit fly research in Latin America, and discuss some possibilities for future studies. I conclude by proposing that on the threshold of the new millennium, the time seems appropriate to follow those early pioneers and once again push forward our understanding of fruit fly biology, ecology and behavior. To achieve this, we need to generate new paradigms and foster creative thinking among our students.

KEY WORDS: Insecta, Anastrepha, Toxotrypana.

When a young student, scientist or government official in Latin America begins to learn about fruit flies for the first time, many myths and misconceptions about these marvelous insects may be forced upon him or her. For example, it is often uncritically accepted that "fruit flies" are notorious pests. Certainly, it would be ludicrous and irresponsible to argue against the fact that some fruit fly species are indeed devastating pests. Names such as the Medfly, Ceratitis capitata (Wiedemann); the Oriental fruit fly, Bactrocera dorsalis (Hendel); the Melon fly, Bactrocera cucurbitae (Coquillett); the Apple Maggot fly, Rhagoletis pomonella (Walsh); the Mexfly, Anastrepha ludens (Loew); the West Indian or Mango fruit fly, Anastrepha obliqua (Macquart) and the Papaya fruit fly, Toxotrypana curvicauda Gerstaecker, jump immediately to mind. But what is often overlooked by the novice, is that pest species represent a distinct minority among the Tephritidae. More specifically, less than $1 \%$ of the more than 4,200 described species are considered to be pests of economic importance. In the case of Anastrepha (a Caribbean and Latin American pest), only seven (Aluja 1994) of the 197 described species (Norrbom et al. 1999b), a mere 3.5\%, are really economically important.

As a consequence of such early imprinting, a reductionist approach is fostered in the young and/or inexperienced scientist, administrator, extension agent or field operator. Reductionism is indeed a useful term to describe the general approach supported by local governments, national or international agen es, private industry and some universities an$\mathrm{d}$ research institutions in the study and control of these insects over the past century. By reductionism, I mean to imply the following: few species, few ideas, and as a consequence, few conceptual advances and breakthroughs, few research leaders, few funding sources and what is even worse, few research topics that are fundable and last but not least, few and narrow management approaches. I say this with all due respect to some of the great think- 
ers and researchers who have contributed to our knowledge of fruit flies in Latin America over the past 100 years: A.L. Herrera, C. Picado, M. McPhail, C.I. Bliss, H.H. Darby, E.M. Knapp, L.C. McAlister, M. Aczél, M. Bezzi, E.E. Blanchard, A. da Costa Lima, D.W. Coquillet, C.H. Curran, C.T. Greene, F. Hendel, E.M. Hering, G.C. Steyskal, A. Stone, E.W. Baker, W.E. Stone, D. Crawford, C.C. Plummer, A.J. Nasca, L.D. Christenson, J.G. Shaw, R.H. Foote, G.L. Bush, D.L. Chambers, D.F. López, R.J. Prokopy, J.S. Morgante, A. Malavasi, D.L. Frías, L.F. Jirón, J. Sivinski, R.A. Wharton, J. Carey, R.A. Zucchi, R. Heath, T. Burk to name but a few. I would also like to mention some members of the new generation of investigators such as A. Norrbom, D. Papaj, J. Hendrichs, D.C. Robacker, P. Liedo, V. Hernández-Ortíz, B. McPheron, G. Steck, L.A.B. Salles, I. Hedström, S. Matioli, A. Kovaleski, R. Sugayama, S. Ovruski, M. Condon, F. DíazFleischer, I. Jácome, and J. Piñero. All t ese people deserve credit for advancing fruit $\mathrm{f}$ y systematics, biology, ecology, and behavior in Latin America, and in this regard, they should all be considered true pioneers in their fields. The fact of the matter is that after 100 years of research, most agricultural practitioners in Latin America and the Caribbean still resort to chemicals and McPhail traps (or modifications thereof) to control and monitor flies because these are the only accessible and cost-effective tools available. Further, too often do growers or government agencies still approach the problem from a very narrow perspective. Most, if not all efforts are concentrated at the orchard level (as opposed to the more appropriate, area-wide view) close to or during the harvest season, with little attention paid to the biology, ecology and behavior of the pest. Why haven't we, as researchers, been able to break this vicious cycle? Part of the reason is that we have paid too little attention to fruit flies and their enemies in nature, and as mentioned before, our approaches have been too rigid and schematic. With few exceptions, it is symptomatic that most of the baseline information on the biol- ogy of fruit flies we use today still comes from studies carried out at the beginning of the century! Unfortunately, after that period of relatively rapid advancement (e.g., Herrera 1900, Herrera et al. 1901, Picado 1920, Crawford 1927, McPhail \& Bliss 1933, Darby \& Knapp 1934, McPhail \& Berry 1936, McPhail 1937, Plummer et al. 1941, Baker et al. 1944, Baker 1945), our research efforts have followed an erratic path. Another explanation for the relatively little progress observed during the last 50 years in the development of fruit fly management alternatives was the availability of fumigants such as ethylene dibromide (EDB) or methyl bromide (MB) (Aluja \& Liedo 1986; J. Reyes - pers. comm.). Growers and government agencies, having easy access to such effective and cheap post-harvest treatments, neglected doing field work. Breaking this heavy dependency and narrow outlook has and will not be easy because it requires a concerted effort by managers and research leaders. The message needs to be clearly stated and understood: when it comes to managing fruit fly problems nothing is more effective than prevention (i.e., avoiding infestations by preventing flies from entering orchards).

Now that we are on the threshold of a new millennium, the time seems appropriate to follow those early pioneers and once again push forward our understanding of fruit fly biology, ecology and behavior. I hope that the next century will be just as full of breakthroughs and new ideas as were those earlier days of scientific discovery. To achieve this, we need to foster creative thinking among our students as well as within the next generation of fruit fly researchers. Why not follow the example of such great Latin American writers as Octavio Paz, Gabriel García-Marquez, Alejo Carpentier, Pablo Neruda, Mario Benedetti, Mario Vargas-Llosa, Juan Rulfo or Juan José Arreola who so brilliantly captured the essence of our mysterious jungles, towns and people. Fruit flies are just as mysterious and therefore deserve more creative attempts to unravel their secrets. We need to also approach the problem from multiple perspectives. For example, we need to give the com- 
parative approach greater acceptance (e.g., compare primitive vs. derived species) and more seriously consider non-pest species as we attempt to build a more robust body of knowledge. In my opinion, the reductionist, single species and pest-only approaches have too many shortcomings to remain as the dominant modes of investigation. We need to expand our horizon and view the problem from many more angles than we have done so far. Finally, and most importantly, we ought to be more humble: fruit fly systems are far too complex and sophisticated to be treated in a superficial way.

Before moving on, and at the risk of sounding naive, I would like to take this opportunity to express a deeply felt concern. I do not want to come across as arrogant or uninformed. I can only ask the reader in advance to consider the good intentions behind my statements, indulge my personal idiosyncrasies, and accept my sincerest apologies should I inadvertently offend any one. But given this unique opportunity to write on fruit flies without any preconditions or limitations, I felt the urge to play the devil's advocate and "challenge" the status quo in an attempt to motivate the new generation of Latin American fruit fly researchers (and hopefully young scientists from other parts of the world) to study these wonderful organisms with an open mind and with greater freedom of thinking. To preface my point, let me draw attention to the following. In the last 80 years, literally hundreds of scientific articles, abstracts (published in congresses or special meeting proceedings) and unpublished reports on fly traps and population fluctuations have been produced. Yet, in our quest to fabricate the perfect trap or identify the key components that drive population fluctuations, we have been left with relatively few defining moments. Why has this been so? In my opinion, and with few recent exceptions (e.g., Robacker et al. 1990, Heath \& Epsky 1993, Heath et al. 1991, 1993, 1996, 2000 ), it is because we have approached our subject from too narrow a view. In particular, we have paid far too little attention to the natural history and behavior of fruit flies in nature, and therefore, we have seriously underestimated the complexity of fruit fly biology and ecology.

In this article, I will argue that too little effort has been devoted to the study of fruit flies in nature and that too much attention has been paid to a few pest species, or in the case of parasitoids, exotic species. At the risk of sounding old-fashioned (especially at a time in which "molecular" is the buzzword), I strongly argue in favor of more natural history studies and of widening our approach to consider non-pest species. I also advocate studies of the areas surrounding or adjacent to commercial orchards because it is here that fly populations increase before invading orchards. Further, I argue in favor of longerterm studies (i.e., considering multi-year, ecological time scales, not just trans-generational population cycles) with the hope that granting agencies will incorporate this consideration in their funding policies. Particularly in the case of research on population dynamics, the current short term approaches will shed little further light on what really drives fruit fly populations (Aluja et al. 1996). In concordance with earlier publications (Aluja \& Liedo 1986 and Aluja 1996), I will again emphasize the fact that the great majority of fruit growers in Latin America are poor, and that because of this, we need to make a much greater effort to develop "....alternatives that are cheap and relatively easy to implement" (Aluja 1996). Finally, I make a plea to strengthen the theoretical and ecological underpinnings of fruit fly research in Latin America, to take more seriously the comparative approach (i.e., to compare as many species as possible, using the most up-to-date phylogenies, in order to support our selection of study organisms), and to act decisively within our own sphere of influence to halt the threat of extinction faced by many fly species. For example, many Anastrepha, Rhagoletis, Toxotrypana, Blepharoneura and Hexachaeta species (to name but a few genera) are severely threatened by deforestation. Are we sufficiently aware of this and have we used our credibility as scientists to enter the 
public debate on this issue?

\section{Fruit Fly Myths}

The American Heritage Dictionary of the English Language (Morris 1978) provides several definitions of a myth. Some of these apply perfectly to the examples I will present here. 1) "A notion based more on tradition or convenience than on fact; a received idea." 2) "Any fictitious or imaginary story, explanation, person or thing." 3) "One of the fictions or half-truths forming part of the ideology of a society."

A famous myth that strained the commercial relationship between Mexico and the United States of America for as many as 80 years, was the idea supported by several interest groups (mainly California avocado growers) that Hass avocados could be infested by several Anastrepha species. Indeed, the supposition that Hass avocados were hosts of the genus Anastrepha was a notion "based more on tradition or convenience than on fact", an "imaginary story" and "a half-truth". Why? As indicated during my testimony at public hearings related to the importation of Mexican Hass avocados into the U.S. (Aluja 1995), supporters of the belief that avocados were hosts of flies in the genus Anastrepha never defined what they meant by "avocado". Even though Bush (1957) reported Anastrepha infestations in avocados, he was reporting on a semi-domesticated, soft skinned variety of avocado that is not grown commercially, and he never specified the species of Persea he was studying. But surely, this report was not related to Persea americana var. Hass. Such was also likely the case with all interceptions of infested avocados at the Mexico-U.S. border noted in USDA-APHISPPQ records.

There are many wild and cultivated plants called avocados, and furthermore, there are many avocado varieties. Which plants were interest groups referring to when relating them to infestations of Anastrepha? As indicated by Aluja (1995) the genus Persea (Clus.) Mill. Gard. Dict. (Lauraceae) is divided into two subgenera: Persea (within which all avocados are classified) and Eriodaphne. In addition, the literature indicates that there are more than fifty species of Persea (Kostermans 1964, Kopp 1966, Gamma-Campillo 1994). For example in the State of Veracruz, Mexico, a recent study (Gamma-Campillo \& Chiappy 1994) identified the following species: A) Subgenus Persea: P. americana Mill. var americana, $P$. americana var. drymifolia (Schlecht \& Cham.), P. americana var guatemalensis and $P$. schiedeana (Ness.) and B) Subgenus Eriodaphne: P. hintonii C.K. Allen, P. longipes (Schlecht.), P. standleyi C.K. Allen, $P$. cinarescens Blake and $P$. donell-smithii Mez.

Was Persea americana var Hass a host of Anastrepha? The answer, as demonstrated by Enkerlin et al. (1993), is no. These authors indicated that Hass avocados exhibit mechanical resistance to the attack of $A$. ludens, $A$. serpentina (Wiedemann) and A. striata Schiner while the unripe fruit is still hanging from the branch. They also showed that Hass avocados can indeed be infested, but only under extreme laboratory conditions. In addition, based on the natural history and behavior of the three Anastrepha species under consideration, as well as the packinghouse conditions for Hass avocados, these authors point out that the likelihood of an infestation is almost zero.

In conclusion, the concern that Hass avocados were hosts of the genus Anastrepha was proven untrue. This incident represents, in my opinion, a classical "fruit fly myth": the consequence of insufficient scientific information, backed by powerful commercial interests, with an unfortunate outcome for an important Mexican agricultural sector as well as Mexico-U.S. relations. Supporters of such a myth or half-truth, never addressed (or wanted to address) the real question: what species and variety of avocado were they talking about? It will be interesting to follow this story now that the most important Hass avocado packing houses in Mexico are being bought or managed by U.S. corporations. Will this new commercial scenario loosen USDA 
restrictions concerning when and where Mexican Hass avocados can be sold within U.S. territory? The lessons from all the above, at least to the scientific community in Latin America are twofold: 1) we need to stand firm and not allow commercial interests to twist reality and 2) we need to generate solid knowledge and produce high quality science, published in high impact, refereed journals, to help support our countries as they negotiate international agreements. In other words, we need to consider the practical impact of our research in much more serious terms.

To avoid generating new myths or perpetuating the prevailing ones, it is necessary to substantiate all host plant records from field collections (i.e., natural infestations). As indicated by Norrbom \& Kim (1988) host records based on laboratory observations should never be substituted for valid field data. Furthermore, when reporting a commercial fruit species as a host, it is necessary to always refer to the variety or cultivar. In my opinion, this rigorous, scientific approach should be the only acceptable basis for any official host plant list and should also be the only valid negotiating basis in international plant protection protocols (such as those sponsored by the North American Plant Protection Organization, NAPPO). Neither commercial interest groups nor government protectionist policies should have any place in this scientific arena.

Related to the above, many people working in government-funded fruit fly programs, and thus influenced by the "pest-species syndrome", have the preconception that fruit flies are exclusively frugivorous and pulp feeding. It is my contention that this has biased field workers in their collection efforts and would explain, in part, why the hosts of so many fruit flies of economic and non-economic importance are still unknown. When in search of new host plants, much of our efforts are involved in collecting visible, pulpy fruits. Obviously, this can steer us away from exiting new discoveries because little attention is paid to galls, shoots, seeds or flowerheads.

For example, upon encountering a ripe, "uninfested" (i.e., a fruit with no trace of larval feeding) fruit of Lucuma salicifolia H.B.K. (=Pouteria campechiana $[$ Kunth] Baehni) or Chrysophyllum mexicanum in Mexico, one can easily make the mistake of reporting this fruit as a non-host, when in fact both plants harbor A. hamata (M. Aluja - unpubl. data). The problem is that our "early imprinting" and "fixed search image" leads us to pay little attention to the seeds, where the larvae of $A$. hamata actually develop. In addition, because of the preconception that only ripe fruit bearing fully developed larvae are worthy of attention, many times we fail to collect unripe fruit. In the case of L. salicifolialA. hamata this would be unfortunate. It turns out that $A$. hamata larvae feed exclusively upon the seeds of unripe fruit and that they exit this fruit while it is still hanging on the tree. Thus, if we limit ourselves to collecting only ripe fruit, we will miss an important fly/host plant interaction.

Another interesting myth is represented by A. fraterculus (Wiedemann). This fly is one of the most widely distributed species of the genus Anastrepha in tropical America (Hernández-Ortíz \& Aluja 1993) and consistently appears in quarantine protocols as a citrus pest. In my opinion, such a conception has been adopted by many without even a timid challenge. Even though there is unequivocal evidence that $A$. fraterculus is indeed able to develop in several citrus species and that its host range is quite wide (Malavasi et al. 1980), the fact is that this species is mainly associated with the Myrtaceae. In a recent study, Aluja and collaborators (Aluja et al. 1999) were able to demonstrate that individual flies from Mexican populations of A. fraterculus were unable to produce any viable progeny in citrus. These authors showed that even under no-choice conditions, females rarely accepted citrus as an oviposition substrate in the laboratory and when such was the case, no larvae eclosed. Importantly, under seminatural conditions (i.e., bagged, fruit-bearing branches into which sexually mature females were released) the only two adults that completed their life cycle in grapefruit were not able to survive for more than 
three days. This contrasts sharply with evidence gathered in such localities as La Rioja and Tucumán, Argentina, where local grapefruit varieties harbour $A$. fraterculus larvae and yield viable adults under field conditions (Hayward 1960, Nasca et al. 1996). Are we dealing with different species or subspecies or, borrowing a concept from Fox \& Morrow (1981), are we dealing with the phenomenon of local specialization?

Referring back to the definition of myth I have adopted, the idea that $A$. fraterculus is a citrus pest may also be "...based more on tradition or convenience than on fact", and at best, it may only be "a half-truth". Anastrepha fraterculus in Mexico is restricted to the Myrtaceae and a few other wild or non-econo ically important fruit trees in the families Combretaceae, Rosaceae, Sapotaceae and Ulmaceae. Why then call it a pest of citrus in this country?

Another widely held myth, at least among certain local government officials and growers, is that the origin of fruit fly populations is within the orchard itself. In my opinion, and with few exceptions, there are no endemic orchard populations. Unfortunately, this misconception has guided local management approaches for too many years. The focus of attention has been the orchard, when in fact it should be the surroundings and periphery, or even more appropriately, the entire fruit-growing region. As Aluja and collaborators showed recently (Aluja \& Birke 1993, Aluja et al. 1996, 1997a, 1997b; also see a recent study on A. fraterculus in apple orchards by Kovaleski [1997]), flies captured in orchards and inflicting damage on them, entered from the periphery. Such a process can be seasonal or daily. Based on this knowledge, management strategies should incorporate the idea of intercepting or killing flies in the area surrounding the orchard (by means of traps, trap crops or, when dealing with extremely high population levels, by applying bait sprays in orchard borders). Such an approach, originally proposed by Aluja \& Liedo (1986) and Aluja (1993a), has been successfully tested by Prokopy et al. (1990) with $R$. pomonella and by Aluja et al. (1997a) with T. curvicauda. In sum, fruit fly management in the tropics should be ideally approached with an areawide view and be part of a broad pest and disease management program (i.e., it must consider more than just fruit flies). Unfortunately, and quoting Aluja (1996), so far and with few exceptions, "fruit fly management has been viewed from a narrow perspective".

Based on pioneering ideas by Geier et al. (1983) and Kogan (1988), Prokopy (1993) proposed a stepwise progression towards integration of pest management practices. His model contemplates the following four levels of integration: 1) integration of multiple management tactics within a single class of pests (which is, by the way, the approach usually followed with fruit flies), 2) integration of multiple management tactics across all classes of pests, 3) integration of combined pest management procedures with an entire system of crop production, and 4) blending the concerns of all groups having a vital interest in pest management.

A step in the right direction would be to divide fruit growing regions according to biogeographical criteria and to tailor management strategies according to the conditions of each region (Aluja \& Liedo 1986). To illustrate, the focus in a semi-arid or desert region with low abundance of native hosts, would be to establish a pest-free area. In contrast, the focus in a region with abundant wild hosts and backyard gardens, would be to decimate fly populations before the commercial fruiting season begins, primarily through the release of parasitoids and sterile flies. Once the fruit starts to ripen, then the focus should shift to the interception of flies in orchard borders. Mapping orchard system dynamics, using tools such as geographic information systems, would be highly recommendable (Nestel et al. 1996, 1997).

The McPhail trap represents one of the most persistent, living myths. Otherwise, how could one explain the fact that this costly and highly inefficient trap has been in use for so long. Aluja et al. (1989) showed that approximately $68 \%$ of the flies landing on a glass 
McPhail trap escape before being captured. This number could actually be lower given the fact that insects could have repeatedly visited the trap (in the study, flies were not marked and thus repeat visits could not be distinguished in the data). Similar results were reported by Prokopy \& Economopoulus (1975) working with Bactrocera oleae (Gmelin). Furthermore, this trap kills many endemic and beneficial insects. In a study during which all insects captured in a McPhail trap were identified, it was found that $50 \%$ of all dipteran families were represented in the catch (M. Aluja, V. Hernández-Ortíz, L. Quiróz \& G. Quintero - unpubl. data). Based on this, and given the fact that the baits used in McPhail traps and insecticide applications are both of proteinaceous nature, it can be inferred that many non-target and beneficial insects are killed when bait sprays are applied.

Also, and despite the fact that most flies need to ingest protein to develop their ovaries, it is unlikely that all species respond equally to the single bait formulation typically used in McPhail traps. As speculated by Aluja et al. (1989), it is possible that several closely related Anastrepha species have different amino acid requirements. Nor is it likely that the McPhail trap performs equally well in all types of environments. Already by 1939 , McPhail had noted that $A$. ludens and $A$. striata were showing different responses to the traps. It has also been shown that the McPhail trap is more efficient in dry seasons and environments than in wet ones (e.g., evergreen rain forest or rainy season within an otherwise dry area) (Cunningham et al. 1978).

The logical question then is, why has this trap been in use for so long? The short answer to this question is that there is no alternative trap available on the market. But why is this? Only until recently, has there been a concerted effort to try to develop a more efficient option (R. Heath - unpubl. data). Judging the process from a distance, it seems that (aside from technical aspects such as formulation issues or materials for trap assemblage) most of the real obstacles have to do with a lack of sufficient information on the basic bi- ology and behavior of the flies. Thus the theme of this article emerges again: we need to make a more serious effort to study the natural history of fruit flies. This means a thorough examination of all the factors that might elicit responses from the insects, including visual and chemical stimuli from native host plants, signals from potential mating partners, and preference criteria used to evaluate potential resting and feeding sites.

To give some general direction to possible natural history studies, I have several suggestions. 1) Working with the odors of native host plants would be more productive than studying introduced hosts such as citrus and mango. This has already proven effective in the case of A. ludens (Robacker et al. 1990). 2) As will be discussed later, when dealing with oogenesis the interaction of biotic and abiotic factors seems to be the key. 3) In the case of baits, flies living in tropical environments would more likely respond to a complex aromatic bouquet containing the odors of the host as well as the pheromones of the sexual partner. All of these suggestions entail long term studies under field and laboratory conditions (e.g., wind tunnels).

Some myths are the result of misidentifications or lack of rigor when citing a questionable source. As pointed out by R.A. Zucchi (pers. comm.), T. curvicauda is wrongly reported as being present in Brazil (e.g., Foote 1965). The problem appears to be a taxonomic one. The genus Mikimyia Bigot has been considered a synonym of Toxotrypana, and the only species placed in Mikimyia (M. furcifera Bigot) has been considered a synonym of $T$. curvicauda (R.A. Zucchi - pers. comm.). Given the fact that the holotype of $M$. furcifera is not known, this problem will not easily be solved in the near future. But since all recent expeditions in search of T. curvicauda in Brazil have failed to find specimens (Zucchi - in press), it can be reasonably concluded that this species is not present in Brazil and should thus be removed from official lists and quarantine protocols.

One last example of a fruit fly myth (actu- 
ally in this case, "rigid approach" would be a more descriptive term) is represented by the exclusive use of introduced (exotic) parasitoids in biological control programs for fruit flies. To illustrate, in Mexico Fopius arisanus Sonan (reported as Opius oophilus Fullaway), Opius novocaledonicus Fullaway, Opius formosanus Fullaway, Opius taiensis Fullaway, Opius vandenboschi Fullaway, Diachasmimorpha longicaudata (Ashmed) (reported as Opius compensans Silvestri), Aceratoneuromyia indica (Silvestri) (Eulophidae) (reported as Syntomosphyrum indicum), Dirhinus giffardi Silvestri, and Pachycrepoideus vindemiae (Rondani) (Pteromalidae) were introduced in the mid1950's (Jiménez-Jiménez 1956, 1958, 1967) and ever since all the attention has been focused on Diachasmimorpha longicaudata (a generalist, larval-pupal parasitoid). Why haven't native species been given an equal opportunity? The answer to such a question is complex.

On the one hand, there are solid theoretical considerations and empirical results showing that new parasite-host associations are more effective than long-evolved associations in successful biological control programs (Hokkanen \& Pimentel 1984). These authors state that "...new exploiter-victim associations should be used as the preferred method in selecting biological control agents" in the management of native pests (also see Hokkanen \& Pimentel 1989). On the other hand, it has been shown that the addition of a second parasitoid species to a system already regulated by a resident species may reduce the degree of control (Kakehashi et al. 1984). Further, and as pointed out by Hochberg (1996), "only a few studies have addressed how increasing the number of coexisting natural enemies in a system may produce an (undesirable) increase in the host's equilibrium level". Finally, and until recently, very little information on the biology of native parasitoids was available in Latin America (Sivinski et al. 1997a, Aluja et al. 1998a).

In sum, I believe the argument for the use of native parasitoids is a convincing one. As will be discussed later, the mass release of native parasitoids should be tested as an alternative to the longer term release of exotic parasitoids, especially in areas where fly populations reach high numbers and from which individual flies are known to move into commercial orchards. Further, in regions were growers are resource-poor, the following actions might be promoted as environmentallyfriendly alternatives to the widespread use of insecticides (details below): 1) the preservation of habitats where parasitoids thrive and 2) the artificial increase of certain parasitoid reservoir, diversity-enhancing and multiplier species of trees (discussed below).

\section{Realities (the real fruit fly world)}

What do we really know about fruit flies and their parasitoids in Latin America? In my opinion, and considering the millions of dollars spend attempting to control them in the past, still far too little. I do not attempt to review here the entire Latin American literature on fruit flies and their parasitoids. Such information can be found in Holler \& Calkins (1986), Wharton (1989), Aluja \& Liedo (1993), Aluja (1994), Sivinski (1996), McPheron \& Steck (1996), Aluja et al. (1996), Anonymous (1996, 1999), López et al. (1999), Aluja \& Norrbom (2000), and Malavasi \& Zucchi (in press).

Arguably, one of the best studied areas in fruit fly biology is systematics. Certain groups like Anastrepha, Blepharoneura, Hexachaeta, Rhagoletis and Toxotrypana are fairly well known, thanks to the pioneering efforts of $\mathrm{M}$. Aczél, M. Bezzi, E.E. Blanchard, A. da Costa Lima, D.W. Coquillet, C.H. Curran, R.H. Foote, C.T. Greene, F. Hendel, E.M. Hering, G.C. Steyskal, A. Stone and the more recent work of R.A. Zucchi (1978, 1981, 1988; et al. 1996), A. Norrbom (Norrbom et al. 1999a, b, 2000 and references therein, Condon \& Norrbom 1994), D.L. Frías (e.g., Frías \& Martínez 1991), C.G. Korytkowski (Korytkowski 1974, Korytkowski \& Ojeda 1968, 1969) and V. Hernández-Ortíz (Hernández-Ortíz 1992). Despite these ef- 
forts, many outstanding questions remain and more work is needed (see section on future research paths). For example, a revision of Toxotrypana is long overdue.

Other topics that have received considerable attention are surveys of fly species and their host plants (Baker et al. 1944, Aluja et al. 1987, 1999 and references therein, Norrbom \& Kim 1988, Hernández-Ortíz \& Pérez-Alonso 1993, Silva et al. 1993, Piedra et al. 1993, Araujo et al. 1996) and studies of population fluctuations in Mexico (GonzálezHernández \& Tejada 1979, Malo et al. 1987, Aluja et al. 1989, 1990, 1996, Aluja 1993b, Celedonio-Hurtado et al. 1995), in Belize (Houston 1981), in Costa Rica (Soto-Manatiú \& Jirón 1989, Jirón \& Hedström 1991), in Colombia (Olarte 1980), in Venezuela (Martínez \& Godoy 1986), and in Brazil (Malavasi \& Morgante 1981, Nascimento \& Zucchi 1981, Fehn 1982, Fernandes 1987, Zahler 1990). Yet with few exceptions, these studies have provided very little of the critical biological information needed to really understand the long term population fluctuations of these organisms. This is because too little attention has been paid to the areas surrounding the orchards where these studies were carried out, and more importantly, because these studies encompassed too short a period of time.

As Aluja et al. (1996) clearly show, shortterm studies (i.e., 1-3 years) can be very misleading. These authors, working in five different mango orchards over five years, demonstrated that even though up to 10 species of fruit flies were captured in an orchard, one species always predominated (A. obliqua). But interestingly, on occasion the second most abundant species (A. ludens) reached higher population levels than the dominant species. Specifically, A. obliqua dominated the site from 1982 to 1985 , but $A$. ludens did so in 1986. In all likelihood, such an important biological result would have gone undetected in a short-term study. Based on this finding, it was recommended that population studies last a minimum of four years in order to have a reasonable chance of detecting important fluc- tuations (Aluja et al. 1996). More recent experiences have lead me to believe that an accurate picture of natural population fluctuations requires a minimum of 10 years of continued trapping. I base this statement on the realization that the highly variable, global weather patterns of recent times have had a tremendous effect on the fruiting patterns of many host plants. As a consequence, many fly populations have crashed at the local level. In order to ascertain the time required for these populations to recover and the periodicity of the new fluctuation patterns, multiyear studies need to be undertaken in Latin America. I urge all researchers to consider both the orchard and its surrounding area when embarking upon these studies. Ideally, a regional approach, which takes into account commercial and semi-commercial orchards, backyard gardens, and patches of native vegetation, should be followed. For this to be possible, considerable funds will be necessary.

Other fields of study in which considerable knowledge on fruit flies has been accrued, albeit under artificial laboratory conditions, are demography and nutritional ecology. Two research groups stand out in Latin America: one lead by F.S. Zucoloto in Brasil and the other directed by P. Liedo in Mexico. Both teams have contributed significantly to the literature on Ceratitis capitata and Anastrepha spp. (Simoes-Braga \& Zucoloto 1981, Zucoloto 1987, 1988, 1989, 1991, 1992, Celedonio et al. 1988, Carey et al. 1992, 1998abc, Message \& Zucoloto 1989, Ferro \& Zucoloto 1989ab, Liedo et al. 1992, Fernandes-da-Silva \& Zucoloto 1993, Cangussu \& Zucoloto 1993, 1997, Liedo \& Carey 1994, Jácome et al. 1995, 1999, Canato \& Zucoloto 1998 and Bravo \& Zucoloto 1998).

Fruit fly behavior has also been an important research topic in Latin America, especially studies of Anastrepha, Blepharoneura, Ceratitis, Rhagoletis and Toxotrypana. But much more work is needed if we are to reach a sufficient degree of understanding of this complex topic. For recent reviews of this literature see Díaz-Fleischer \& Aluja (2000), 
Aluja et al. (2000), Condon \& Norrbom (2000), Yuval \& Hendrichs (2000), Eberhard (2000), Prokopy \& Papaj (2000) and Landolt (2000). Also see Aluja \& Norrbom (2000) for an overview of the behavior of tephritid groups and various related families.

An area of investigation that has received much recent attention in Latin America is native parasitoids. In Brasil for example, recent efforts by R.A. Zucchi, his students and his collaborators, have yielded important information on the abundance of parasitoids in non-agricultural settings (Nascimento et al. 1979, Aguiar et al. 1992, Canal et al. 1994, 1995, Leonel et al. 1995, Araujo et al. 1996, Guimarães et al. 1999). Related studies have been carried out in Mexico (GonzálezHernández \& Tejada 1979, Aluja et al. 1990, Hernández-Ortíz et al. 1994, López et al. 1999), Guatemala (Eskafi 1990), Costa Rica (Wharton et al. 1981, Jirón \& Mexzon 1989), Colombia (Yépes \& Vélez 1989), Venezuela (Katiyar et al. 1995) and Argentina (Turica \& Mallo 1961, Nasca 1973, de Santis 1980, Fernández-de-Araoz \& Nasca 1984, Díaz 1986, Ovruski 1995). Furthermore, studies by J. Sivinski, M. López, M. Aluja and their collaborators have shed light on some basic aspects of parasitoid biology, ecology and behavior (Sivinski et al. 1997ab, 1998, Sivinski 2000, Aluja et al. 1998a, Hodgson et al. 1998, Menezes et al. 1998, López et al. 1999, Eben et al. - in press, Montoya et al. submitted, in press, Ruíz et al. - submitted). Notable findings from these studies include: 1) the widespread occurrence and relative abundance of Doryctobracon areolatus, 2) the widespread occurrence of diapause among native (as well as some exotic) parasitoids in tropical environments, 3 ) the high specificity of the native pupal endoparasitoid Coptera haywardi (which may make it possible to replace the exotic, generalist, ectoparasitoid Pachycrepoideus vindemiae in augmentative biological control programs [Guillén et al. 1999]), 4) the complex associations of members of the parasitoid guilds in tree canopies, and 5) the great importance of native vegetation as natural reservoirs for parasitoid spe- cies.

In the last instance, Aluja \& Sivinski (submitted) proposed the following classification for parasitoid reservoirs: 1) reservoir species, 2) diversity enhancing species and 3) multiplier species. Some multiplier species, such as Spondias mombin, can produce up to 207 parasitoids per kilogram of fruit or over 4,000 parasitoids per tree (Aluja \& Sivinski - submitted). These authors further propose that wild parasitoid reservoirs should become an integral part of regional fruit fly management programs. Among other recommendations, they propose the establishment of nurseries to propagate plant species that act as parasitoid reservoirs, and the reintroduction of such reservoir plants as part of national reforestation programs. An added benefit of managing reservoir plants is that many represent valuable timber sources for the poor, rural farming family. Such is the case with Tapirira mexicana, a tree with wood equal to the quality of mahogany (Terrazas \& Wendt 1995).

Undoubtedly two areas where progress has been significant are postharvest treatments (e.g., Sharp 1992, Mangan \& Ingle 1992, 1994) and the sterile insect technique (e.g., Gilmore 1989, Hendrichs et al. 1995, Rendón et al. 1998). Unfortunately in the latter case, almost all current research efforts are aimed at the Medfly (C. capitata). In my opinion, an equivalent amount of attention is long overdue in the case of Anastrepha. In this respect, the Mexican Campaña Nacional contra las Moscas de la Fruta is leading the way and has been able to simultaneously mass rear A. ludens, $A$. obliqua and A. serpentina. Recently, two of these species ( $A$. ludens and A. obliqua) were sterilized and mass released to simultaneously eradicate these species in Baja California Sur, Mexico (J. Reyes - pers. comm.). Similar efforts, in combination with mass releases of parasitoids and other biorrational control strategies (such as habitat manipulation) would be welcome in many other parts of Latin America. 
Before finishing this section, I would like to mention a critical aspect of fruit fly biology that managers need to take more seriously. Many important stages in the life history of fruit flies are completed away from the orchard, occurring instead in the surrounding landscape matrix. That is where our principal management efforts need to be directed. This is especially true in the case of biological control programs. For example, massreared larval and pupal parasitoids (such as Coptera haywardi, Doryctobracon areolatus or Utetes anastrephae) might be released adjacent to commercial mango orchards, in areas near wild host species such as Spondias purpurea. This would drastically reduce fly populations without the need for insecticides or the widespread removal of wild hosts plants. Such parasitoid treatments might be supplemented by sterile fly releases in order to minimize the impact of flies that escaped parasitism.

\section{Dreams (future research paths)}

As stated at the beginning of this article, fruit flies are complex and sophisticated organisms. If we are to make headway in understanding them, we need to incorporate this complexity into our research protocols (granted of course, that we have gathered enough information on the natural history of the particular species of interest). I will illustrate my point using the following examples.

First, oogenesis has been approached either from a descriptive perspective (Bressan \& Teles 1991, Martínez et al. 1995, Ramírez et al. 1996) or by using simple experimental protocols that consider only one variable at a time. Even though such approaches have yielded useful information, a recent study by Lagunes (1998) clearly showed that ovary maturation is driven by chemical and social factors, diet, and the age and availability of host plants. Furthermore, Fitt (1986) showed that patterns of oogenesis varied sharply between r- and K-selected species of Bactrocera. A similar pattern is observed in Anastrepha. Such information underscores the need for solid natural history studies.

Another good example of the complexity of fruit fly biology can be found in studies of nutritional ecology. Many Latin American studies describe the effects of artificial diets on life history traits such as fecundity or longevity. As already noted, the elegant work of F.S. Zucoloto stands out in this respect. What is missing from such work is a more natural setting. Typically, only artificial diets presented on a continuous basis are offered to flies. The danger of such experimental protocols is that flies will either exhibit uncharacteristic responses or that the laboratory findings will have little bearing on what happens in nature.

To illustrate this last point, Jácome et al. (1999) recently documented the existence of a "junk food syndrome" in Anastrepha serpentina. That is to say, when females were offered the choice between sucrose and protein, they preferred the sucrose (i.e. junk food) over the protein. This phenomenon has a physiological basis. Tseng et al. (1983) and Jones et al. (1992) working with another fly (stable fly, Stomoxys calcitrans (Linnaeus)), reported that carbohydrates can block behavioral reflexes associated with hunger for protein. The discovery of this phenomenon in fruit flies is interesting, but how common is it in nature?

Furthermore, how relevant are many experimental protocols to natural scenarios? For example, it is unlikely that a fly in nature encounters high quality food every day, yet many experimental designs call for a continuously available food source. Obviously, extrapolation from laboratory to field conditions would be difficult under these circumstances and results would have to be treated cautiously. Underscoring this point is a recent study of individual feeding patterns in A. serpentina. In this investigation, Jácome et al. (1999) discovered that flies do not feed every day. In fact, on occasion three days can pass without a single feeding bout being recorded for a particular individual (all flies were individually marked in this study). The results of this study force us to reconsider the basic premise 
of the continual feeding protocol of many experimental designs in order to ask a more fundamental question. If flies in nature neither feed daily nor encounter high quality foods on a daily basis, then shouldn't our experiments simulate such natural conditions, rather than introduce the confounding effects of artificial or unnatural scenarios?

A final example of the complexity alluded to at the beginning of this section is the effect that environmental variability can have on such phenomena as diapause or on certain life history traits. For example, Aluja et al. (1998a) showed that diapause is widespread among many native (and a few exotic) parasitoids under the ambient conditions of natural tropical environments, but it has yet to be recorded for parasitoids maintained in laboratory colonies under controlled conditions. Specifically, neither Aganaspis pelleranoi nor Odontosema anastrephae exhibited diapause when reared under a constant temperature regime, but when field collected, particularly between September and December, these species entered a diapause period which lasted up to 11 months.

Life history traits such as longevity can also be influenced by environmental variation. For example, individuals of Doryctobracon areolatus maintained under strict laboratory conditions lived only one third the amount of time as individuals maintained under variable (i.e., fluctuating) field conditions (M. Aluja, M. López \& J. Sivinski - unpubl. inf.). Aluja et al. (2000) indicate that mortality schedules and maximum longevity in strictly monophagous, univoltine species (e.g., $A$. crebra Stone or $A$. bezzii Costa Lima) differ greatly from those of polyphagous, multivoltine species (e.g., A. ludens or $A$. serpentina), and that these differences probably reflect unique life history adaptations to environmental variability. These authors indicate that "...when adult $A$. ludens and $A$. serpentina were kept in $30 \times 30 \times 30 \mathrm{~cm}$ Plexiglass cages under laboratory conditions, $3.3 \%$ and $8.3 \%$, respectively, were alive after 120 days. In contrast, when $A$. crebra and $A$. bezzii adults were maintained in exactly the same conditions, $60.0 \%$ and $46.6 \%$, respectively, were alive after 120 days". Aluja et al. (2000) speculate that A. crebra and $A$. bezzii adults "...must survive for long periods to cope with the high environmental variability which determines the fruit production schedule of its host plants (Quararibea funebris (Llave) Vischer and Sterculia apetala (Jacq.) Karst. for A. crebra and A. bezzii, respectively)". Adults of A. ludens and $A$. serpentina, on the other hand, exploit a series of host species that appear in a progressive fashion throughout most of the year and thus may not need to live as long. These results suggest that if we are to truly understand fruit fly biology, we need to look at different life history strategies among pest and non-pest species.

All the above clearly demonstrates the role that environmental variability (e.g., varying temperature regimes) plays in shaping the life history of flies and their parasitoids. Based on this evidence, I believe it is necessary to spend many more years in the field collecting biologically meaningful data, before we plunge into sophisticated laboratory studies. In my opinion, the opposite tactic is too often followed. And without baseline natural history data, it's no wonder why so little progress is being made in fruit fly ecology, biology and behavior. The desperate need for more field data also underscores the inadequacy of current funding programs. As a rule, funds are only provided for short term studies and under very inflexible conditions. Long term field investigations, supported by flexible funding mechanisms, must be developed if we hope to make any substantial progress in the future.

As I indicated at the beginning of this paper, high among the priority list of future research on fruit flies is the need to deepen our knowledge of natural history. For example, in the case of host plant relationships we need to expand the scope of our surveys and go beyond simple lists. Instead, what is critically needed is the phenology of host plant use at the local level. For example, we might ask how a multivoltine species like $A$. obliqua is able to shift from one host plant to another 
during the year and compare its performance on each host species. We might also measure critical life history parameters for flies, such as fecundity and life expectancy, as they vary in association with each host.

Also, we need to determine what strategies different fly species use to survive the long periods of time in which no alternative host plants are available. To continue with the example of A. obliqua, in central Veracruz, Mexico, this species uses the following host plants (in order of occurrence): Spondias purpurea (May-June) > Mangifera indica (June-July) > Spondias mombin and Spondias spp. (August-September) > Tapirira mexicana (October-November). From December through April it is unclear how the flies survive until Spondias purpurea fruits are again available.

Aluja et al. (submitted) recently discovered that Myrciaria floribunda (Myrtaceae) can serve as a host to A. obliqua during the months of March through April. The problem is that this host is also used by A. bahiensis Costa Lima and $A$. fraterculus, and as a result, there is probably strong competition for its use (all three species have been obtained in one single fruit). Further, M. floribunda is heavily predated by local mammals and birds. So, even though it does represent an alternative host plant, and one that fruits at a time when no other host is available, it is unlikely that $M$. floribunda can maintain large populations of fruit flies for long periods of time. Thus, the mystery of how A. obliqua survives from December until April is still unresolved.

Given the fact that diapause has never been reported in Anastrepha, what are the probable mechanisms that would permit individuals of A. obliqua, and for that matter many other species, to survive such long periods of time? One recent discovery that sheds light on this subject, is the delayed development of larvae and pupae that has been reported in A. fraterculus (Kovaleski 1997). This author showed that in the apple growing regions of Rio Grande do Sul and Santa Catarina in Brasil, when temperatures drop during the winter months, development of immature forms is reduced significantly. A similar phenomenon has been recently discovered in the Medfly (Ceratitis capitata). In this case, Papadopoulus et al. (1996) and shortly thereafter Israely et al. (1997), demonstrated that larvae can remain inside the fruit in a suspended state of development during the cold months of the year. With this strategy they can also survive the long period after the last host plant of the season, starting with early varieties of apples and overwintering in late varieties such as Granny-Smith (Papadopoulus et al. [1996], Israely et al. [1997]).

In the case of $A$. obliqua, a fly that lives in warmer regions, such a phenomenon has not been documented. In our studies, all flies collected from the last host plant of the season (T. mexicana) emerged during the same season (Aluja et al. 1998a). This was in sharp contrast to most parasitoid species, which entered a diapause phase (Aluja et al. 1998a). Thus, it appears that adults likely survive prolonged periods of time in the absence of available host plants. In the case of $A$. alveata Stone, a strictly monophagous species, Aluja et al. (2000) report that adults can live up to 431 days. In A. obliqua, the longest life span of an individual in the laboratory is 185 days for a female (P. Liedo \& M. Aluja - unpubl. inf.). Thus, it is quite likely that after emerging under T. mexicana trees, A. obliqua adults seek moist spots in canyons were they are able to survive until suitable hosts are again available. Nevertheless, this needs to be formally documented.

There are still other areas of fruit fly research that I believe need greater attention. Specifically, I refer to such topics as: 1) population dynamics (e.g. the role of biotic and abiotic mortality factors), 2) behavior (e.g. foraging, oviposition and sexual behaviors, as well as long range movements), 3) physiology (e.g. the interactive role of biotic and abiotic factors in oogenesis and male sexual maturation), 4) nutritional ecology (as already noted, more emphasis should be placed on understanding the key interactive elements) and 5) chemical ecology (e.g. the chemical 
characterization of volatile host plant compounds and insect sexual pheromones). In all cases, it would be very productive to make as many interspecific comparisons as possible (see Aluja et al. 2000 for further details).

The area of behavior deserves special attention. As noted before, a recently published book (Aluja \& Norrbom 2000) provides a thorough review of the phylogeny and evolution of behavior in tephritid flies. I will not repeat here what is aptly discussed by many authorities there. Nevertheless, there are a few aspects that I believe should be mentioned. For example, we are still ignorant about what distinguishes successful from unsuccessful courtships in lekking fruit flies, or if female criteria for choosing male traits vary geographically (Eberhard 2000). Large gaps still exist in our understanding of the sexual biology of flies, in particular questions remain to be answered in regard to the determinants of male copulatory and reproductive success (Yuval \& Hendrichs 2000), as well as the ecological conditions that determine why some tropical species form leks. Larval behavior seems particularly neglected (Condon \& Norrbom 2000, Yuval \& Hendrichs 2000). For example, in the Trypetinae, virtually nothing is known about the temporal and spatial differences in the utilization of fruit by larvae (Drew \& Yuval 2000) or about larval responses to natural enemies (Yuval \& Hendrichs 2000).

Some of the questions on the evolution of fruit fly behavior could be resolved by a consideration of families related to the Tephritidae (i.e., the Lonchaeidae, Pallopteridae, Piopilidae, Ulidiidae (= Otitidae), Platystomatidae and Richardiidae (Sivinski 2000). As this author points out, it would be particularly interesting to compare the ecology and mating behavior of lekking and swarming species (e.g., compare the Tephritidae with the Pyrgotidae).

Of particular importance are studies of behavior under field conditions (Aluja et al. 2000). For example, little is known about behavior of flies when they are not on host trees (Landolt 2000). As noted by Headrick
\& Goeden (2000), field studies will continue to be challenging, but are necessary in order to verify laboratory-based observations.

The need for more efficient monitoring mechanisms has already been addressed. However, I would point out again that we must continue to develop traps, not only for flies but also for parasitoids. With the exception of the attempts by Messing \& Wong (1992) no other studies have addressed this interesting topic. Furthermore, and most importantly, we really need to make an effort to correlate trap captures with larval infestation levels. This, of course, should be done once a substitute for the McPhail trap is available. Without such studies, we will never be able to finetune our management strategies (e.g. using economic thresholds to determine the need for intervention). It is difficult to understand why this critical gap in information has not already been addressed. Finally, and as mentioned in the beginning of this article, we need to constantly remind ourselves that most growers in Latin America are very poor. As a result, it is unlikely that they will be able to purchase costly traps. Based on this knowledge, we need to make a greater effort to design inexpensive traps and baits that are available locally. These may not be as efficient as the more costly models, but for a poor farmer with little access to capital the goal is not blemishfree fruit, but rather a reduction in the damage inflicted by flies. For these growers (who may lose 60 to $100 \%$ of their harvest), a 20 to $30 \%$ reduction in infestation levels is significant.

As an example of a cost effective trap for the poor grower, Piñero (1995) and Vázquez (1995), following the pioneering work of Hedström (1988), successfully tested human urine and chicken feces as a bait for wet traps (following previous reports by Hedström 1988). In these studies, human urine never attracted as many flies as hydrolyzed protein, but on occasions the proportion of immature females was higher in the urine-baited traps than in the protein-baited traps. This is really quite significant for the poor farmer who wants to know the fly population levels in his or- 
chard. At virtually no cost to the farmer, a recycled plastic bottle baited with the right concentration of human urine will suffice.

Before finishing, let me briefly review some of the alternatives to insecticides that we now have available for the control of fruit flies (also see Aluja 1996). Some of the newest, environmentally-safe developments are: 1) photosensitive dyes as substitutes for insecticides in toxic baits like malathion. These dyes have to be consumed by the insect, which then dies when exposed to sunlight. Used in combination with specific food bait for adult fruit flies, they do not kill non-target organisms (Mangan \& Moreno 1995, Moreno \& Mangan 1995, Lee et al. 1997, Heitz et al. 1997), 2) synthetic host marking pheromones to repel Anastrepha flies from treated fruit (Aluja et al. 1998b), 3) the use of the toxin "spinosad" derived from the fungus Sacaropolyspora spinosa. This toxin acts on any insect by contact or by ingestion, and can be made more specific when combined with fruit fly food baits (Peck \& McQuate 1999), and 4) the design of papaya orchards to trap out immigrating individuals of $T$. curvicauda (Aluja et al. 1997a).

In conclusion, the dawn of a new century offers the opportunity for many young scientists to get involved in fruit fly studies using a different mindset. The time is ripe for new paradigms in fruit fly research and management approaches. Let us not wait any longer to take advantage of this historic opportunity.

\section{Acknowledgements}

I thank Roberto A. Zucchi and Sueli S. Martinez for inviting me to write this article. I further acknowledge the important support of Jesús Reyes-Flores. Jesús has understood the value of the long-term financing of scientific endeavors and I want to recognize his important contribution to opening new paradigms in fruit fly research. I also acknowledge the important intellectual input of John Sivinski. All the research on fruit fly parasitoids and some of the studies cited here on fruit flies are part of collaborative projects with John. Furthermore, I thank Dan Bennack, Diana Pérez-Staples and Larissa Guillén for helping me to write this paper and Francisco Díaz-Fleischer for providing some of the references cited herein. Isabel Jácome, Jaime Piñero, Francisco Díaz-Fleischer, Maurilio López, Andrea Birke, Everardo Bigurra, Enrique Piedra, Gloria Lagunes, Gemma Quintero and Larissa Guillén deserve credit for their contribution to the research reported here. I thank Diana Pérez-Staples, Jesús Reyes-Flores, Gary Steck and Jaime Piñero for constructive criticisms on an earlier draft of this manuscript. Original research reported here was financially supported by the following donors: Campaña Nacional Contra las Moscas de la Fruta (SAGAR-IICA), International Foundation for Science (project 051/93), Consejo Nacional de Ciencia y Tecnología (CONACyT)(projects D111903537 \& 0436P-N9506), Secretaría de Educación Pública (project DGICSA902467), U.S. Department of Agriculture (USDA) - Office of International Cooperation and Development (OICD)(Project No. 198-23), USDA-ARS (Agricultural Research Service) (Agreement No. 58-6615-3-025), Comisión Nacional para el Conocimiento y Uso de la Biodiversidad (project No. H-296) and the Sistema de Investigación Regional del Golfo de México (SIGOLFO-CONACyT) (project 96-01-003-V).

\section{Literature Cited}

Aguiar, E.L., F.L. Leonel, E.B. Menezes \& R.A. Zucchi. 1992 Natural enemies of the fruit fly Anastrepha spp. on different hosts in the Itaguai county, State of Rio de Janeiro, Brazil. In First meeting of the working group on fruit flies of the Western Hemisphere, San José, Costa Rica.

Aluja, M. 1993a. The study of movement in tephritid flies: Review of concepts and recent advances, p. 105-113. In M. Aluja $\&$ P. Liedo (eds.). Fruit Flies: Biology and Management. New York, Springer, 492p. 
Aluja, M. 1993b. Manejo Integrado de las Moscas de la Fruta. 2nd ed. Trillas, Mexico, D.F. 252 p.

Aluja, M. 1994. Bionomics and management of Anastrepha. Annu. Rev. Entomol. 39: 155-173.

Aluja, M. 1995. Testimony by Martín Aluja. Public Hearings related to the importation of Mexican Hass avocados into the United States of America (August 17-18, 1995). U.S. Dept. of Agriculture - Plant Protection and Plant Inspection Service. Washington D.C., USA.

Aluja, M. 1996. Future trends in fruit fly management, pp. 309-320. In B.A. McPheron \& G.J. Steck (eds.), Fruit Fly Pests: World Assessment on their Biology and Management. DelRay Beach, FL., St. Lucie Press, 586 p.

Aluja, M. \& P. Liedo. 1986. Future perspectives on integrated management of fruit flies in Mexico, pp. 12-48. In M. Mangel (ed.), Pest Control: Operations and Systems Analysis. New York, Springer, $465 \mathrm{p}$.

Aluja, M. \& A. Birke. 1993. Habitat use by adults of Anastrepha obliqua (Diptera: Tephritidae) in a mixed mango and tropical plum orchard. Ann. Entomol. Soc. Am. 86: 799-812.

Aluja, M. \& P. Liedo (eds). 1993. Fruit flies: biology and management. New York, Springer, $492 \mathrm{p}$.

Aluja, M. \& A. Norrbom (eds.). 2000. Fruit Flies (Diptera: Tephritidae): Phylogeny and Evolution of Behavior. Boca Raton, Fl, USA. CRC Press. 968 p.

Aluja, M. \& J. Sivinski. Pest management through tropical tree conservation. Bioscience (submitted).
Aluja, M., M. López \& J. Sivinski. 1998a. Ecological evidence for diapause in four native and one exotic species of larvalpupal fruit fly (Diptera: Tephritidae) parasitoids in tropical environments. Ann. Entomol. Soc. Am. 91: 821-833.

Aluja, M., F. Díaz-Fleischer, A.J.F. Edmunds \& L. Hagmann. 1998b. Aislamiento, determinación estructural, síntesis, actividad biológica y aplicación como agente de control de la feromona marcadora de hospedero y sus derivados de las moscas de la fruta del género Anastrepha (Diptera: Tephritidae). Número de registro ante el Instituto Mexicano de la Propiedad Industrial (IMPI): 988732. Registered on October 21, 1998.

Aluja, M., M. Cabrera, J. Guillén, H. Celedonio \& F. Ayora. 1989. Behavior of Anastrepha ludens, A. obliqua, and A. serpentina (Diptera: Tephritidae) on a wild mango tree (Mangifera indica) harbouring three McPhail traps. Insect. Sci. Appl. 10: 309-318.

Aluja, M., J. Piñero, I. Jácome, F. DíazFleischer \& J. Sivinski. 2000. Behavior of flies in the genus Anastrepha (Trypetinae: Toxotrypanini), pp. 375406. In M. Aluja \& A.L. Norrbom (eds.), Fruit Flies (Diptera: Tephritidae): Phylogeny and Evolution of Behavior. Boca Raton, Fl, USA. CRC Press. 968p.

Aluja, M., D. Pérez-Staples, J. Piñero, R. Macías, B. McPheron \& V. HernándezOrtíz. 1999. Are Mexican populations of Anastrepha fraterculus (Diptera: Tephritidae) able to infest oranges and grapefruit?, p. 79-80. In Memoirs of the 3rd meeting of the working group on fruit flies of the Western Hemisphere. Guatemala City, Guatemala, 4-9 July 1999. 
Aluja, M., J. Guillén, G. de la Rosa, M. Cabrera, H. Celedonio, P. Liedo \& J. Hendrichs. 1987. Natural host plant survey of the economically important fruit flies (Diptera: Tephritidae) of Chiapas. Fla. Entomol. 70: 329-338.

Aluja, M., H. Celedonio-Hurtado, P. Liedo, M. Cabrera, F. Castillo, J. Guillén \& E. Rios. 1996. Seasonal population fluctuations and ecological implications for management of Anastrepha fruit flies (Diptera: Tephritidae) in commercial mango orchards in Southern Mexico. J. Econ. Entomol. 89: 654-667.

Aluja, M., A. Jiménez, M. Camino, J. Piñero, L. Aldana, V. Castrejón \& M.E. Valdés. 1997a. Habitat manipulation to reduce papaya fruit fly Toxotrypana curvicauda (Diptera: Tephritidae) damage: orchard design, use of trap crops and border trapping. J. Econ. Entomol. 90: $1567-1576$.

Aluja, M., J. Guillén, P. Liedo, M. Cabrera, E. Rios, G. de la Rosa, H. Celedonio \& D. Mota. 1990. Fruit infesting tephritids (Dipt.: Tephritidae) and associated parasitoids in Chiapas, Mexico. Entomophaga 35: 39-48.

Aluja, M., M. López, J. Piñero, C. Ruíz, A. Zúñiga, E. Piedra, F. Díaz-Fleischer \& J. Sivinski. New Anastrepha spp., Toxotrypana curvicauda, Rhagoletis zoqui, R. sp. and Hexachaeta sp. (Diptera: Tephritidae) host plant and distribution records in Mexico. Proc. Entomol. Soc. Wash. (submitted).

Aluja, M., A. Jiménez, J. Piñero, M. Camino, L. Aldana, M.E. Valdés, V. Castrejón, I. Jácome, A. Dávila \& R. Figueroa. 1997b. Daily activity patterns and within-field distribution of papaya fruit flies (Diptera: Tephritidae) in Morelos and Veracruz, Mexico. Ann.
Entomol. Soc. Am. 90: 505-520.

Anonymous. 1996. Memoirs of the "Second Meeting of the Working Group on Fruit Flies of the Western Hemisphere". Viña del Mar, Chile. 100 p.

Anonymous. 1999. Memoirs of the "Third Meeting of the Working Group on Fruit Flies of the Western Hemisphere”. 1999. Guatemala, Guatemala. 131 p.

Araujo, E.L., R.A. Zucchi \& N.A. Canal. 1996. Caracterização e ocorrência de Anastrepha zenildae Zucchi (Diptera: Tephritidae) e sues parasitóides (Hymenoptera: Braconidae) numa nova planta hospedeira, no Rio Grande do Norte. An. Soc. Entomol. Brasil 25: 147150.

Baker, E.W. 1945. Studies on the Mexican fruit fly known as Anastrepha fraterculus. J. Econ Entomol. 38: 95-100.

Baker, A.C., A.C. Stone, C.C. Plummer \& M. McPhail. 1944. A review of studies on the Mexican fruit fly and related Mexican species. USDA-APHIS Misc. Publ. No. 531, 154 p.

Bravo, I.S.J. \& F.S. Zucoloto. 1998. Performance and feeding behavior of Ceratitis capitata: comparison of a wild population and a laboratory population. Entomol. Exp. Appl. 87: 67-72.

Bressan, S. \& M. C. Teles. 1991. Longevidade e curva de sobrevivência de três espécies do gênero Anastrepha Schiner, 1868 (Diptera, Tephritidae) em laboratório. Rev. Bras. Entomol. 35: 685690.

Bush, G. 1957. Some notes on the susceptibility of avocados in Mexico to attack by the Mexican fruit fly. J. Rio Grande Valley Hort. Soc. 6: 75-95. 
Canal, N.A.D., R.A. Zucchi, N.M. da Silva \& F.L. Leonel Jr. 1994. Reconocimiento de las especies de parasitoides (Hym.: Braconidae) de moscas de las frutas (Dip.: Tephritidae) en dos municipios del Estado de Amazonas, Brasil. Bol. Museo Entomol. Univ. del Valle 2: 1-17.

Canal, N.A.D., R.A. Zucchi, N.M. da Silva \& S. Silveira-Neto. 1995. Análise faunística dos parasitóides (Hymenoptera, Braconidae) de Anastrepha spp. (Diptera: Tephritidae) em Manaus e Iranbuda, Estado do Amazonas. Acta Amazonica 25: 235-246.

Canato, C.M. \& F.S. Zucoloto. 1998. Feeding behavior of Ceratitis capitata (Diptera: Tephritidae): Influence of carbohydrate ingestion. J. Insect. Physiol. 44: 149-155.

Cangussu, J.A. \& F.S. Zucoloto. 1993. Influence of partial malnutrition on egg production by Ceratitis capitata (Diptera: Tephritidae). Rev. Brasil. Biol. 53: 155158.

Cangussu, J.A. \& F.S. Zucoloto. 1997. Effect of protein sources on fecundity, food acceptance, and sexual choice by Ceratitis capitata (Diptera: Tephritidae). Rev. Brasil. Biol. 57: 611-618.

Carey, J.R., P. Liedo, D. Orozco \& J.W. Vaupel. 1992. Slowing of mortality rates at older ages in large medfly cohorts. Science 258: 457-461.

Carey, J.R., P. Liedo, H.-G. Müller, J.-L. Wang \& J.-M. Chiou. 1998a. Relationship of age patterns of fecundity to mortality, longevity, and life time reproduction in a large cohort of Mediterranean fruit fly females. J. Gerontol. 53A: 245-251.

Carey, J.R., P. Liedo, H.-G. Müller, J.L. Wang \& J.W. Vaupel. 1998b. A simple graphical technique for displaying individual fertility data and cohort survival: case study of 1'000,000 Mediterranean fruit fly females. Func. Ecol. 12: 359-363.

Carey, J.R., P. Liedo, H.-G. Müller, J.-L. Wang \& J.W. Vaupel. 1998c. Dual modes of aging in Mediterranean fruit fly females. Science 281: 996-998.

Celedonio-Hurtado, H., P. Liedo, M. Aluja \& J. Guillén. 1988. Demography of Anastrepha ludens, A. obliqua and A. serpentina (Diptera: Tephritidae) in Mexico. Fla. Entomol. 71: 111-120.

Celedonio-Hurtado, H., M. Aluja \& P. Liedo. 1995. Adult population fluctuations of Anastrepha species (Diptera: Tephritidae) in tropical orchard habitats of Chiapas, Mexico. Environ. Entomol. 24: 861-869.

Condon, M.A. \& A.L. Norrbom. 1994. Three sympatric species of Blepharoneura (Diptera: Tephritidae) on a single species of host (Gurania spinulosa, Cucurbitaceae): new species and new taxonomic methods. Syst. Entomol. 19: 279-304.

Condon, M.A. \& A.L. Norrbom. 2000. Behavior of flies in the genus Blepharoneura (Blepharoneurinae), pp. 157-174. In M. Aluja \& A.L. Norrbom (eds.), Fruit Flies (Diptera: Tephritidae): Phylogeny and Evolution of Behavior. Boca Raton, Fl, USA. CRC Press. 968p.

Crawford, D.L. 1927. Investigation of Mexican fruit fly (Anastrepha ludens Loew) in Mexico. Calif. Dept. Agr. Month. Bull. 16: 422-445.

Cunningham, R.T., S. Nakagawa, D.Y. Suda \& T. Urago. 1978. Tephritid fruit fly trapping: Liquid food baits in high and low rainfall climates. J. Econ. Entomol. 
71: $762-763$.

Darby, H.H. \& E. M. Knapp. 1934. Studies of the Mexican fruit fly Anastrepha ludens (Loew). USDA Tech. Bull. 444: 1-20.

Díaz, N.B. 1986. Ampliación de la distribución geográfica de cinipoideos parasitoides en la República Argentina y Brasil. Rev. Soc. Entomol. Argentina 44: 32.

Díaz-Fleischer, F. \& M. Aluja. 2000. Behavior of tephritid flies: A historical perspective, pp. 39-69. In M. Aluja \& A. L. Norrbom (eds.), Fruit Flies (Diptera: Tephritidae): Phylogeny and Evolution of Behavior. Boca Raton, Fl, USA. CRC Press. 968p.

Drew \& Yuval. 2000. The evolution of fruit fly feeding behavior, pp. 731-749. In M. Aluja \& A. L. Norrbom (eds.), Fruit Flies (Diptera: Tephritidae): Phylogeny and Evolution of Behavior. Boca Raton, Fl, USA. CRC Press. 968p.

Eben, A., B. Benrey, J. Sivinski \& M. Aluja. The influence of host species and host plants on preference and performance of Diachasmimorpha longicaudata (Hymenoptera: Braconidae). Environ. Entomol. (in press).

Eberhard, W. 2000. Sexual behavior and sexual selection in the Mediterranean fruit fly, Ceratitis capitata (Dacinae: Ceratitidini), pp. 459-489. In M. Aluja \& A. L. Norrbom (eds.), Fruit Flies (Diptera: Tephritidae): Phylogeny and Evolution of Behavior. Boca Raton, Fl, USA. CRC Press. 968p.

Enkerlin, W., J. Reyes, A. Bernabé, A. Sánchez, J. Toledo \& M. Aluja. 1993. Estatus del aguacate "Hass" como hospedero de tres especies de moscas de la fruta del género Anastrepha, (Diptera:
Tephritidae), en condiciones forzadas y naturales. Agrociencia (Serie Protección Vegetal) 4: 329-348.

Eskafi, F.M. 1990. Parasitism of fruit flies Ceratitis capitata and Anastrepha spp. (Diptera: Tephritidae) in Guatemala. Entomophaga 35: 355-362.

Fehn, L.M. 1982. Influência dos fatores meteorológicos na flutuação e dinâmica de população de Anastrepha spp. Pesq. Agropec. Bras. 17: 533-544.

Fernandes, O.A. 1987. Estudos bioecológicos e avaliação de danos causados por moscas-das-frutas (Diptera: Tephritidae) en Citrus sinensis Osbeck var. pera. M.S. dissertation, University of São Paulo, Brasil.

Fernandes-da-Silva, P.G. \& F.S. Zucoloto. 1993. The influence of host nutritive value on the performance and food selection in Ceratitis capitata (Diptera: Tephritidae). J. Insect Physiol. 10: 883810.

Fernandez-de-Araoz, D. \& A.J. Nasca. 1984. Especies de braconidae (Hymenoptera: Ichneumonidae) parasi- toides de moscas de las frutas (Diptera: Tephritidae) colectados en la provincia de Tucuman. CIRPON (Argentina) 2: 3746.

Ferro, M.I.T. \& F.S. Zucoloto. 1989a. Influência da nutrição protéica no desenvolvimento da glândula salivar de machos de Anastrepha obliqua Macquart, 1835 (Diptera: Tephritidae). Científica 17: 189-193.

Ferro, M.I.T. \& F.S. Zucoloto. 1989b. Effect of the quantity of dietary amino acids on egg production and layings by Ceratitis capitata (Diptera: Tephritidae). Brazilian J. Med. Biol. Res. 23: 525-531. 
Fitt, G.P. 1986. The influence of a shortage of host the specificity of oviposition behaviour in species of Dacus (Diptera: Tephritidae). Physiol. Entomol. 11: 133143.

Fox, L.R. \& P.A. Morrow. 1981. Specialization: species property or local phenomenon? Science 211: 887-893.

Foote, R.H. 1965. Family Tephritidae. p. 658678. In A. Stone, C.W. Sabrosky, W.W. Wirth, F.H. Foote \& J.R. Coulson. A Catalog of the Diptera of America North of Mexico, ARS/USDA, Agric. Handbook No. 276, 1696 p.

Frías, L.D. \& H. Martínez. 1991. Estudio taxonómico en Rhagoletis tomatis Foote (Diptera: Tephritidae). Acta Entomol. Chilena 16: 247-254.

Gamma-Campillo, L. 1994. Studies on the systematics and ethnobotany of the subgenus Persea. Ph.D. dissertation. Univ. of California, Riverside, Calif., USA. 294 p.

Gamma-Campillo, L. \& C. Chiappy. 1994. Ecología y conservación del género Persea en el Estado de Veracruz, p. 115129. In G. Castillo-Campos \& M.T. Mejía-Saulés (eds.), Problemática Ambiental en el Estado de Veracruz: los Recursos Vegetales. Jointly published by Colegio Profesional de Biólogos de Veracruz, A.C., Gobierno Estado de Veracruz y Universidad Veracruzana, Xalapa, Veracruz, México.

Geier, P.W., L.R., Clark \& D.T. Briese. 1983. Principles for the control of arthropod pests. 1. Elements and functions involved in pest control. Prot. Ecol. 5: 1-96.

Gilmore, J.E. 1989. Sterile insect technique (SIT) - overview. pp. 353-363. In A.S. Robinson \& Hooper, G. (eds.) Fruit Flies. their Biology, Natural Enemies and Control v. 3B. Amsterdam. Elsevier.

González-Hernández, A. \& L.O. Tejada. 1979. Fluctuación de la población de Anastrepha ludens (Loew) y de sus enemigos naturales en Sargentia greggii S. Watts. Folia Entomol. Mex. 41: 49-60.

Guillén, L., M. Aluja, I. Jácome, M. López, M. Equihua \& J. Sivinski. 1999. Coptera haywardi (Hymenoptera: Dipariidae), an ecologically friendly alternative to the use of Pachycrepoideus vindemiae (Hymenoptera: Pteromalidae), p. 40-41. In Memoirs of the 3rd meeting of the working group on fruit flies of the Western Hemisphere. Guatemala City, Guatemala, 4-9 July 1999.

Guimarães, J.A., R.A. Zucchi, N.B. Díaz, M.F. de Souza Filho \& M.A. Uchoa F. 1999. Espécies de Eucoilinae (Hymenoptera: Cynipoidea: Figitidae) parasitóides de larvas frugívoras (Diptera: Tephritidae e Lonchaeidae) no Brasil. An. Soc. Entomol. Brasil 28: 263-273.

Hayward, K.J. 1960. Insectos tucumanos perjudiciales. Rev. Ind. Agr. Tuc. 42: 3144.

Headrick \& Goeden. Behavior of flies in the subfamily Tephritinae, pp. 671-707. In M. Aluja \& A.L. Norrbom (eds.), Fruit Flies (Diptera: Tephritidae): Phylogeny and Evolution of Behavior. Boca Raton, Fl, USA. CRC Press. 968p.

Heath, R.R., A. Manukian, N.D. Epsky, J. Sivinski, C.O. Calkins \& P.J. Landolt. 1993. A bioassay system for collecting volatiles while simultaneously attracting tephritid fruit flies. J. Chem. Ecol. 19: 2395-2410.

Heath, R.R., \& N.D. Epsky. 1993. Recent progress in the development of attractants for monitoring the Mediterranean fruit fly 
and several Anastrepha species, pp. 463472. In Management of insect pests: Nuclear and related molecular and genetic techniques. Interntl. Symp. Manag. of Insect Pests, IAEA, Vienna.

Heath, R.R., N.D. Epsky, A. Jimenez, B.D. Dueben, P.J. Landolt, W.L. Meyer, M. Aluja, J. Rizzo, M. Camino, F. Jeronimo, \& R.M. Baranowski. 1996. Improved pheromone-based trapping systems to monitor Toxotrypana curvicauda (Diptera: Tephritidae). Fla. Entomol. 79: 37-48.

Heath, R.R., P.J. Landolt, D.C. Robacker, B.O. Dueben, N.D. Epsky. 2000. Sexual pheromones of tephritid flies: clues to unravel phylogeny and behavior, pp. 793809. In M. Aluja \& A.L. Norrbom (eds.), Fruit Flies (Diptera: Tephritidae): Phylogeny and Evolution of Behavior. Boca Raton, Fl, USA. CRC Press. 968p.

Heath, R.R., P.J. Landolt, J.H. Tumlinson, D.L. Chambers, R.E. Murphy, R.E. Doolittle, B.D. Dueben, J. Sivinski \& C.O. Calkins. 1991. Analysis, synthesis, formulation, and field testing of three major components of male Mediterranean fruit fly pheromone. J. Chem. Ecol. 17: 1925-1940.

Hedström, I. 1988. Una sustancia natural en la captura de moscas del género Anastrepha Schiner (Diptera: Tephritidae). Rev. Biol. Trop. 36: 269272.

Heitz, J., R.L. Mangan \& D.S. Moreno. 1997. Patent: Phototoxic insecticidal composition and method for controlling insect populations. U.S. Patent No. 5,676,959 (issued on October 14, 1997).

Hendrichs, J., G. Franz \& P. Rendón. 1995. Increased effectiveness and applicability of the sterile insect technique through male-only releases for control of
Mediterranean fruit flies during fruiting seasons. J. Appl. Entomol. 5: 371-377.

Hernández-Ortíz, V. 1992. El género Anastrepha Schiner en Mexico (Diptera: Tephritidae): Taxonomía, distribución y sus plantas huespedes. Xalapa, Veracruz, México. Instituto de Ecología y Sociedad Mexicana de Entomología. 162.

Hernández-Ortíz, V. \& M. Aluja. 1993. Listado de especies del género neotropical Anastrepha (Diptera: Tephritidae) con notas sobre su distribución y plantas hospederas. Folia Entomol. Mex. 88: 89-105.

Hernández-Ortíz, V. \& R. Pérez-Alonso. 1993. The natural host plants of Anastrepha (Diptera: Tephritidae) in a tropical rain forest of Mexico. Fla. Entomol. 76: 447-460.

Hernández-Ortíz, V., R. Pérez-Alonso \& R.A. Wharton. 1994. Native parasitoids associated with the genus Anastrepha (Dipt.: Tephritidae) in Los Tuxtlas, Veracruz, Mexico. Entomophaga 39: 171178.

Herrera, A.L. 1900. El gusano de la naranja. Bol. Soc. Agrícola Mexicana 14: 61-69.

Herrera, A.L., A.F. Rangel \& L. De la Barrera. 1901. El gusano de la fruta (Instrypeta ludens I. D. B.). (Mex) Com. Parasit. Agr. Bot. 1: (5)-44, 76-86, 115124, 170, 184-196, 291.

Hochberg, M.E. 1996. Consequences for host population levels of increasing natural enemy species richness in classical biological control. Amer. Nat. 147: $307-$ 318.

Hodgson, P.J., J. Sivinski, G. Quintero \& M. Aluja. 1998. Depth of pupation and survival of fruit fly (Anastrepha spp.: Tephritidae) pupae in a range of 
agricultural habitats. Environ. Entomol. 27: $1310-1314$.

Hokkanen, H.M.T. \& D. Pimentel. 1984. New approach for selecting biological control agents. Can. Entomol. 116: 11091121.

Hokkanen, H.M.T. \& D. Pimentel. 1989. New associations in biological control: theory and practice. Can. Entomol. 121: 829-840.

Holler, T.C. \& C.O. Calkins. 1986. Anastrepha ludens (Loew) (Diptera: Tephritidae): A selected bibliography (1888-1986). J. Rio Grande Hort. Soc. 39: 41-53.

Houston, W.W.K. 1981. Fluctuation in numbers and the significance of the sex ratio of the Mexican fruit fly, Anastrepha ludens caught in McPhail traps. Entomol. Exp. Appl. 30: 140-150.

Israely, N., B. Yuval, U. Kitron, D. Nestel. 1997. Population fluctuations of adult Mediterranean fruit flies (Diptera: tephritidae) in a Mediterranean heterogenous agricultural region. Environ. Entomol. 26: 1263-1269.

Jácome, I., M. Aluja \& P. Liedo. 1999. Impact of adult diet on demography and population parameters of the tropical fruit fly Anastrepha serpentina (Diptera: Tephritidae). Bull. Entomol. Res. 89: 165-175.

Jácome, I., M. Aluja, P. Liedo \& D. Nestel. 1995. The influence of adult diet and age on lipid reserves in the tropical fruit fly Anastrepha serpentina (Diptera: Tephritidae) J. Insect. Physiol. 41: 10791086.

Jiménez-Jiménez, E. 1956. Las moscas de la fruta y sus enemigos naturales. Fitófilo 16: 4-11.
Jiménez-Jiménez, E. 1958. Empleo de enemigos naturales para el control de insectos que constituyen plagas agrícolas en la República Mexicana. Fitófilo 21: 5-30.

Jiménez-Jiménez, E. 1967. Pachycrepoideus vindemiae (Rond.) (Hymenoptera: Pteromalidae), enemigo natural de las moscas de la fruta. Fitófilo 56: 31-38.

Jirón, L.F. \& L. Hedström. 1991. Population fluctuation of economic species of Anastrepha (Diptera: Tephritidae) related to mango fruiting phenology in Costa Rica. Fla. Entomol. 74: 98-105.

Jirón, L.F. \& R.G. Mexzon. 1989. Parasitoid hymenopterans of Costa Rica: Geografical distribution of the species associated with fruit flies (Diptera: Tephritidae). Entomophaga 34: 53-60.

Jones, C.J., D.E. Milne, R.S. Patterson, E.T. Schreiber \& J.A. Milio. 1992. Nectar feeding by Stomoxys calcitrans (Diptera: Muscidae): Effects on reproduction and survival. Environ. Entomol 21: 141-147.

Kakehashi, N., Y. Suzuki \& Y. Iwasa. 1984. Niche overlap of parasitoids in hostparasitoid systems: its consequence to single versus multiple introduction controversy in biological control. J. Appl. Ecol. 21: 115-131.

Katiyar, K.P., J. Camacho, F. Geraud \& R. Matheus. 1995. Parasitoides Hymenopteros de moscas de la frutas (Diptera: Tephritidae) en la región Occidental de Venezuela. Rev. Fac. Agron. (LUZ) Maracaibo, Venezuela. 12: 303-312.

Kogan, M. 1988. Integrated pest management theory and practice. Entomol. Exp. Appl. 49: 59-70.

Kopp, L.E. 1966. A taxonomic revision of 
the genus Persea in the Western Hemisphere. Memoirs of the New York Botanical Garden 14: 1-120.

Korytkowski, C.G. 1974. Una nueva especie del género Anastrepha Schiner (Diptera: Tephritidae). Rev. Per. Entomol. 17: 1-3.

Korytkowski, C.G. \& D.P. Ojeda. 1968. Especies del género Anastrepha Schiner 1868 en el nor-oeste peruano. Rev. Per. Entomol. 11: 32-70.

Korytkowski, C.G. \& D.P. Ojeda. 1969. Distribución ecológica de especies del género Anastrepha Schiner en el noroeste peruano. Rev. Per. Entomol. 12: 7195.

Kostermans, A.J.G.H. 1964. Bibliographia Lauracearum. Ministry of National Research. P.T. Djulie “Archipel”, Bogor, Indonesia. $+1450 \mathrm{p}$.

Kovaleski, A. 1997. Processos adaptativos na colonização da maçã (Malus domestica L.) por Anastrepha fraterculus (Wied.) (Diptera: Tephritidae) na região de Vacaria, RS. Ph.D. Thesis Univ. de São Paulo. São Paulo, Brasil. 122p.

Lagunes-Hernández, G. 1998. Efecto del contexto social, dieta previa, y la presencia de hospedero artificial en el desarrollo de los ovarios de dos especies de Anastrepha (Diptera: Tephritidae) con diferentes estrategias de oviposición. Bsc. Thesis, Universidad Veracruzana, Xalapa, Veracruz, México.

Landolt, P. 2000. Behavior of fruit flies in the genus Toxotrypana (Trypetinae: Toxotrypanini), pp. 363-373. In M. Aluja \& A.L. Norrbom (eds.), Fruit Flies (Diptera: Tephritidae): Phylogeny and Evolution of Behavior. Boca Raton, Fl, USA. CRC Press. 968p.

Lee, C.J., A.B. DeMilo, D.S. Moreno \&
R.L. Mangan. 1997. Identification of the volatile component of E802 Mazoferm steepwater, a condensed fermented corn extractive highly attractive to the Mexican fruit fly (Diptera: Tephritidae). J. Agric. Food Chem. 45: 2327-2331.

Leonel, F.L., Jr., R.A. Zucchi \& R.A. Wharton. 1995. Distribution and tephritid hosts (Diptera:) of braconid parasitoids (Hymenoptera) in Brazil. Int. J. Pest Management 41: 208-213.

Liedo, P. \& J.R. Carey. 1994. Mass rearing of Anastrepha (Diptera: Tephritidae) fruit flies: a demography analysis. J. Econ. Entomol. 87: 176-180.

Liedo, P., J.R. Carey, H. Celedonio \& J. Guillén. 1992. Size specific demography of three species of Anastrepha fruit flies. Entomol. Exp. Appl. 63: 135-142.

López, M., M. Aluja \& J. Sivinski. 1999. Hymenopterous larval-pupal parasitoids of Anastrepha flies (Diptera: Tephritidae) in Mexico. Biol. Cont. 15: 119-129.

Malavasi, A. \& J.S. Morgante. 1981. Adult and larval population fluctuation of Anastrepha fraterculus and its relationship to host availability. Environ. Entomol. 10: 275-278.

Malavasi, A., J.S. Morgante \& R.A. Zucchi. 1980. Biologia de "moscas-das-frutas" (Diptera: Tephritidae). I:Lista de hospedeiros e ocorrência. Rev. Brasil. Biol. 40: 9-16.

Malavasi, A. \& R.A. Zucchi (eds.). Moscasdas-frutas de importância econômica no Brasil. Holos Editora. (in press).

Malo, E., P.S. Baker \& J. Valenzuela. 1987. The abundance of species of Anastrepha (Diptera: Tephritidae) in the coffee producing area of coastal Chiapas, Southern Mexico. Folia Entomol. Mex. 
73: $125-140$.

Mangan, R.L. \& D.S. Moreno. 1995. Development of phloxine B and uranine bait for control of Mexican fruit fly, $\mathrm{p}$. 276. In J.R. Heitz \& D.R. Downum (eds.), ACS Symposium series 616, lightactivated pest control. Amer. Chem. Soc. Washington D.C.

Mangan, R.L. \& S.J. Ingle. 1992. Forced hot-air quarantine treatment for mangos infested with West Indian fruit fly. J. Econ. Entomol. 85: 1859-1864.

Mangan, R.L. \& S.J. Ingle. 1994. Forced hot-air quarantine treatment for grapefruit infested with Mexican fruit fly (Diptera: Tephritidae). J. Econ. Entomol. 87: 15741579.

Martínez, A.J. \& F. Godoy. 1986. Influencia de los factores meteorologicos sobre la fluctuacion poblacional de Anastrepha obliqua Macquart (Diptera: Tephritidae) en mango. Agron. Trop. (Venezuela) 36: 55-65.

Martínez, I., V. Hernández-Ortíz \& R. Luna. 1995. Desarrollo y maduración sexual en Anastrepha serpentina (Wiedemann) (Diptera: Tephritidae). Acta Zool. Mex. (n.s.) 65: 75-88.

McPhail, M. 1937. Relation of time of day, temperature and evaporation to attractiveness of fermenting sugar solutions to the Mexican fruit fly. J. Econ. Entomol. 30: 793-799.

McPhail, M. 1939. Protein lures for fruit flies. J. Econ. Entomol. 32: 758-761.

McPhail, M. \& C.I. Bliss. 1933. Observations on the Mexican fruit fly and some related species in Cuernavaca, Mexico, in 1928 and 1929. U.S. Dept. Agric. Circ. 255.
McPhail, M. \& N.O. Berry 1936. Observations on Anastrepha pallens (Coq.) reared from wild fruits in the lower Rio Grande Valley of Texas during the spring of 1932. J. Econ. Entomol. 29: 405-410.

McPheron, B.A. \& G.J. Steck (eds). 1996. Fruit Fly Pests: A World Assesment of their Biology and Management. Delray Beach, FL. USA, St. Lucie Press, 586 p.

Menezes, E., J. Sivinski, T. Holler, M. Aluja, F. Jerónimo \& E. Ramirez. 1998. Development of Coptera haywardi (Hymenoptera: Diapriidae) in irradiated and unirradiated pupae of the Caribbean fruit fly and the Mediterranean fruit fly (Diptera: Tephritidae). Fla. Entomol. 81: 567-569.

Message C.M., F.S. Zucoloto. 1989. Efeitos das misturas de alguns alimentos na produção de óvulos en Anastrepha obliqua (Diptera: Tephritidae). Rev. Bras. Zool. 6: 595-598.

Messing, R.H. \& T.T.Y. Wong. 1992. An effective trapping method for field studies of opiine braconid parasitoids of tephritid fruit flies. Entomophaga 37: 391-396.

Montoya, P., P. Liedo, B. Benrey, J. Cancino, J.F. Barrera, J. Sivinski \& M. Aluja. Biological control of Anastrepha in mango through augmentative releases of Diachasmimorpha longicaudata (Ashmead) (Hymenoptera: Braconidae). Biol. Cont. (submitted)

Montoya, P., P. Liedo, B. Benrey, J.F. Barrera, J. Cancino, \& M. Aluja. Functional response and superparasitsm of Diachasmimorpha longicaudata (Hymenoptera: Braconidae), a parasitoid of fruit flies (Diptera: Tephritidae). Ann. Entomol. Soc. Am. (in press). 
Moreno, D.S. \& R.L. Mangan. 1995. Responses of the Mexican fruit fly (Diptera: Tephritidae) to two hydrolyzed proteins and incorporation of ploxine $B$ to kill adults, p.276. In J.R. Heitz \& D.R. Downum (eds.), ACS Symposium series 616, Light-Activated pest control, American Chemical Society, Washington, D.C.

Morris, W. (ed.). 1978. The American Heritage Dictionary of the English Language. Boston, USA. Houghton Mifflin Co. 1550 p.

Nasca, A.J. 1973. Parasitos de "Moscas de la fruta" establecidos en algunas zonas de Tucuman. Rev. Agron. N.O. Argentina 10: 31-43.

Nasca, A.J., J.A. Zamora, L.E. Vergara \& H.E. Jaldo. 1996. Hospederos de moscas de los frutos en el Valle de Antinaco-Los Colorados, provincia de La Rioja, República Argentina. CIRPON Rev. Invest. 10: 19-24.

Nascimento, A.S., A.L. Mesquita \& R.A. Zucchi. 1979. Parasitism of pupae of Anastrepha spp. Dip.: Tephritidae by Doryctobracon areolatus (Szépligeti, 1911) (Hym.: Braconidae) in citrus and tropical fruits, p. 239-246. In CNPQ/ Association of the Japan shipbuilding industry, "Japan-Brazil symposium on science and technology" Vol II. São Paulo, Brazil.

Nascimento, A.S. do \& R.A. Zucchi. 1981. Dinâmica populacional das moscas-dasfrutas no Recôncavo Baiano. II. Flutuação populacional. Pesq. Agropec. Bras. 17: 969-980.

Nestel, D., B. Yuval \& U. Kitron. 1997. Spatial and temporal patterns of a Medfly population in an heterogenous agricultural Mediterranean landscape, $p$. 23. In International Atomic Energy
Agency (ed.), Working material of a third research coordination workshop on "Medfly mating behaviour studies under field cage conditions". Tel Aviv, Israel 1519 September 1997. 36p.

Nestel, D., N. Israely, B. Yuval \& U. Kitron. 1996. Population dynamics of the Mediterranean fruit fly in an heterogenous Mediterranean agricultural landscape, $\mathrm{p}$. 85-90. In J.G. Morse (ed.), Proceedings of the Exotic Fruit Fly Research Symposium. Riverside, CA, USA. College of Natural and Agricultural Science, University of California. 96p.

Norrbom, A.L. \& K.C. Kim. 1988. A list of the reported host plants of the species of Anastrepha (Diptera: Tephritidae). USDA-APHIS. 81-52, 114 p.

Norrbom, A.L., L.E. Carroll \& A. Freidberg. 1999a. Status of knowledge, p. 9-47. In F.C. Thompson (ed.), Fruit fly Expert Identification System and Biosystematic Information Database. Myia 1998, 9: 524p \& Diptera data dissemination disk (CD-ROM) (1998). 1:Inameslfruitfly. [Classification, reviews of phylogeny, biology, etc.].

Norrbom, A.L., L.E. Carroll, F. C. Thompson, I.M. White \& A. Freidberg. 1999b. Systematic database of names, pp. 65-251 \& 7104 records. In F.C. Thompson (ed.), Fruit Fly Expert Identification System and Biosystematic Information Database. Myia 1998, 9: 524p \& Diptera data dissemination disk (CD-ROM) (1998). 1: Inameslfruitfly. [Catalog/database of genera and species, type data, distributions, etc.].

Norrbom, A.L, R.A. Zucchi \& V. Hernández-Ortíz. 2000. Phylogeny of Anastrepha and Toxotrypana based on morphology, pp. 299-342. In M. Aluja \& A.L. Norrbom (eds.), Fruit Flies (Diptera: Tephritidae): Phylogeny and Evolution of 
Behavior. Boca Raton, FL. CRC Press. 968p.

Olarte, W.E. 1980. Dinámica poblacional del complejo constituido por las moscas de las frutas Anastrepha fraterculus en el medio ecologico del sur de Santander, Bucaramanga, Colombia. M.Sc. Dissertation, Universidad Industrial de Santander, Colombia.

Ovruski, S.M. 1995. Pupal and larval-pupal parasitoids (Hymenoptera) obained from Anastrepha spp. and Ceratitis capitata (Dipt.: Tephritidae) pupae collected in four localities of Tucumán Province, Argentina. Entomophaga 40: 367-370.

Papadopoulus, N.T., J.R. Carey, B.I. Katsoyanos \& N.A. Kouloussis. 1996. Overwintering of the Mediterranean fruit fly (Diptera: Tephritidae) in Northern Greece. Ann. Enotmol. Soc. Am. 89: 526534.

Peck, S.L. \& G.T. McQuate. 1999. Control of Mediterranean fruit flies using bait sprays of spinosad and phloxine B: possible malathion alternative for fruit fly control programmes, p. 55. In Memoirs of the 3rd Meeting of the Working Group on Fruit Flies of the Western Hemisphere. Guatemala City, Guatemala, 4-9 July 1999.

Picado, C.T. 1920. Historia del gusano de la guayaba. Publicaciones del Colegio de Señoritas, Serie A. Estudios científicos. 5-28.

Piedra, E., A. Zuñiga \& M. Aluja. 1993. New host plant and parasitoid record in Mexico for Anastrepha alveata Stone (Diptera: Tephritidae). Proc. Entomol. Soc. Wash. 95: 127

Piñero, J. 1995. Respuesta de Anastrepha ludens (Loew), A. obliqua (Macquart), A. serpentina (Wiedemann) y A. striata
(Schiner) (Diptera: Tephritidae) antes diversas sustancias volatiles. B.Sc. Thesis. Universidad Veracruzana, Xalapa, Veracruz, Mexico.

Plummer, C.C., M. McPhail \& J.W. Monk. 1941. The yellow chapote: a native host of the Mexican fruit fly. U.S. Dept. Agr. Tech. Bull. 755.

Prokopy, R.J. 1993. Stepwise progress toward IPM and sustainable agriculture. The IPM Practitioner 15: 1-4.

Prokopy, R.J. \& D.R. Papaj. 2000. Behavior of flies of the genus Rhagoletis, Zonosemata and Carpomya (Trypetinae: Carpomyina), pp. 219-252. In M. Aluja \& A.L. Norrbom (eds.), Fruit Flies (Diptera: Tephritidae): Phylogeny and Evolution of Behavior. Boca Raton, FL. CRC Press. 968p.

Prokopy, R.J. \& P. Economopoulos. 1975. Attraction of laboratory cultured and wild Dacus oleae flies to sticky coated McPhail traps of different colors and odors. Environ. Ent. 4: 187-192.

Prokopy, R.J., S.A. Johnson \& M.A. O'Brien. 1990. Second-stage integrated management of apple arthropod pests. Entomol. Exp. Appl. 54: 9-20.

Ramírez-Cruz, A., V. Hernández-Ortíz \& I. Martínez. 1996. Maduración ovárica en la "Mosca de la Guayaba" Anastrepha striata Schiner (Diptera: Tephritidae). Acta Zool. Mex. (n.s.) 69: 105-116.

Rendón, P., D. McInnis, D. Lance \& J. Steward. 1998. Comparison of Medfly male-only and bisex releases in large scale field trials in Guatemala. In Proceedings of 5th International Symposium on fruit flies of economic importance. Penang, Malysia, June 1-5, 1998.

Robacker, D.C., J.A. García \& W.G. Hart. 
1990. Attraction of a laboratory strain of Anastrepha ludens (Diptera: Tephritidae) to the odor of fermented chapote fruit and to pheromones in laboratory experiments. Environ. Entomol. 19: 403-408.

Ruíz, L.C., J.L. Cancino, M. Aluja, S.M. Ovruski, J. Sivinski \& P. Liedo. Adaptation to mass rearing of the fruit fly parasitoid Doryctobracon crawfordi (Viereck): a demographic analysis. Entomol. Exp. Appl. (submitted).

Santis de, L. 1980. Catálogo de los Himenópteros brasileños de la serie parasítica, incluyendo Bethyloidea. Publi. Comisión Invest. Cient. Prob. Bs. As.

Sharp, J.L. 1992. Hot-air quarantine treatment for mango infested with Caribbean fruit fly (Diptera: Tephritidae). J. Econ. Entomol. 85: 2302-2304.

Silva, da N.M, S.S. Neto \& R.A. Zucchi. 1993. The natural host plants of Anastrepha in the State of Amazonas, Brazil, p. 353-357. In B.A. McPheron \& G.J. Steck (eds.), Fruit fly pest, a world assesment of their biology and management. Delray Beach, FL. USA, St. Lucie Press, 586p.

Simões-Braga M.A. \& F.S. Zucoloto. 1981. Estudos sobre a melhor concentração de aminoácidos para moscas adultas de Anastrepha obliqua (Diptera: Tephritidae). Rev. Bras. Biol. 41: 75-79.

Sivinski, J. 1996. The past and potential of biological control of fruit flies, p. 369375. In B.A. McPheron \& G. Steck (eds.), Fruit Fly Pests: a World Assesment of their Biology and Management. Delray Beach, FL., St. Lucie Press, 586p.

Sivinski, J. 2000. Breeding habits and sex in families closely related to the Tephritidae: Opportunities for comparative studies of the evolution of fruit fly behavior, p. 23-
37. In M. Aluja \& A.L. Norrbom (eds.), Fruit Flies (Diptera: Tephritidae): Phylogeny and Evolution of Behavior. Boca Raton, Fl, USA. CRC Press. 968p.

Sivinski, J., K. Vulinec, E. Menezes \& M. Aluja. 1997a. The bionomics of Coptera haywardi (Ogloblin) (Hymenoptera: Diapriidae) and other pupal parasitoids of tephritid fruit flies (Diptera: Tephritidae). Biol. Cont. 11: 193-202.

Sivinski, J., M. Aluja \& M. López. 1997b. Spatial and temporal distributions of parasitoids of Mexican Anastrepha species (Diptera: Tephritidae) within the canopies of fruit trees. Ann. Entomol. Soc. Am. 90: 604-618.

Sivinski, J., M. Aluja \& T. Holler. 1999. The distributions of the Caribbean fruit fly, Anastrepha suspensa (Tephritidae) and its parasitoids (Hymenoptera: Braconidae) within the canopies of host trees. Fla. Entomol. 82: 73-81.

Sivinski, J., M. Aluja, T. Holler \& A. Eitam. 1998. Phenological comparison of two braconid parasitoids of the Caribbean fruit fly (Diptera: Tephritidae). Environ. Entomol. 27: 360-365.

Soto-Manatiú, J. \& L.F. Jirón. 1989. Studies on the population dynamics of the fruit flies, Anastrepha (Diptera: Tephritidae) associated with mango (Mangifera indica L.) in Costa Rica. Trop. Pest Manage. 35: 425-427.

Terrazas, T. \& T. Wendt. 1995. Systematic wood anatomy of the genus Tapirira Aublet (Anacardiaceae) - a numerical approach. Brittonia 47: 109-129.

Tseng, J.M., C.J. Jones \& J.A. Hogsette. 1983. Nectar feeding and the stable fly, Stomoxys calcitrans (Diptera: Muxcidae). J. Fl. Anti-Mosquito Assoc. 54: 40-41. 
Turica, A. \& R.G. Mallo. 1961. Observaciones sobre la población de las "Tephritidae" y sus endoparásitos en algunas regiones citrícolas Argentinas. IDIA 145-161.

Vázquez A. 1995. Comportamiento de Anastrepha ludens (Loew), A. serpentina (Wiedemann), A. stritata (Schiner) y A. obliqua (Macquart) (Diptera: Tephritidae) en respuesta a diversos cebos alimenticios. B.Sc. Thesis. Universidad Veracruzana, Xalapa, Veracruz, Mexico.

Wharton, R. 1989. Classical biological control of fruit-infesting tephritidae, $\mathrm{p}$. 303-314. In A.S. Robinson \& G. Hooper (eds.), Fruit flies: their Biology, Natural Enemies and Control. Amsterdam, Elsevier.

Wharton, R.A., F.E, Gilstrap, R.H. Rhode, M.M. \& W.G. Hart. 1981. Hymenopterous egg-pupal and larval-pupal parasitoids of Ceratitis capitata and Anastrepha spp. (Diptera: Tephritidea) in Costa Rica. Entomophaga 26: 285-290.

Yépes, R.F. \& A.R. Vélez. 1989. Contribución al conocimiento de las moscas de las frutas (Tephritidae) y sus parasitoides en el departamento de Antioquia. Rev. Fac. Nac. Agron. Medellín 42: 73-98.

Yuval, B. \& J. Hendrichs. 2000. Behavior of flies in the genus Ceratitis (Dacinae: Ceratitidini), pp. 429-457. In M. Aluja \& A.L. Norrbom (eds.), Fruit Flies (Diptera: Tephritidae): Phylogeny and Evolution of Behavior. Boca Raton, FL. CRC Press. 968p.

Zahler, P.M. 1990. Moscas-das-frutas em trees pomares do Distrito Federal: Levantamento de especies e fluctuacao populacional. Cienc. Cult. (Brasil) 42: 177-182.

Zucchi, R.A. 1978. Taxonomia das espécies de Anastrepha Schiner, 1868 (Diptera: Tephritidae) assinaladas no Brasil. Ph.D. Thesis Univ. de São Paulo, Escola Sup. Agr. "Luiz de Queiroz", Piracicaba, Brasil. 105 p.

Zucchi, R.A. 1981. Anastrepha Schiner, 1868 (Dipt.: Tepritidae): Novas sinonímias. Rev. Brasileira Entomol. 25: 289-294.

Zucchi, R.A. 1988. Moscas-das-frutas (Dip.: Tephritidae) no Brasil: taxonomia, distribuição geográfica e hospedeiros, p. 1-10. In H.M.L. Souza (coord.), Moscasdas-frutas no Brasil. Fundação Cargill.

Zucchi, R.A. Taxonomia. In Moscas-dasfrutas de importância econômica no Brasil (Malavasi, A. \& R. A. Zucchi, eds.). Holos Editora. (in press).

Zucchi, R.A., N.M. da Silva \& S.S. Neto. 1996. Anastrepha species from the Brazilian Amazon: distribution, host and lectotype designations, p. 259-264. In B.A. McPheron \& G. Steck (eds.), Fruit Fly Pests, a World Assessment of their Biology and Management. Florida, USA, St. Lucie Press, 586 p.

Zucoloto, F.S. 1987. Feeding habits of Ceratitis capitata (Diptera: Tephritidae): can larvae recognize a nutritionally effective diet? J. Insect Physiol. 33: 349353.

Zucoloto, F.S. 1988. Qualitative and quantitative competition for food in Ceratitis capitata (Diptera: Tephritidae). Rev. Bras. Biol. 48: 523-526.

Zucoloto, F.S. 1989. Efeitos das misturas de alguns alimentos na produção de óvulos em Anastrepha obliqua (Diptera: Tephritidae). Rev. Bras. Zool. 6: 595-598.

Zucoloto, F.S. 1991. Effects of flavour and nutritional value on diet selection by Ceratitis capitata larvae (Diptera: 
Tephritidae). J. Insect Physiol. 37: 21-25.

Zucoloto, F.S. 1992. Egg production by
Ceratitis capitata (Diptera: Tephritidae) fed with different carbohydrates. Rev. Bras. Ent. 36: 235-240. 